\title{
Combined effects of ocean acidification and elevated temperature on feeding, growth, and physiological processes of Antarctic krill Euphausia superba
}

\author{
Grace K. Saba ${ }^{1, *}$, Abigail B. Bockus ${ }^{2}$, C. Tracy Shaw ${ }^{3}$, Brad A. Seibel ${ }^{3}$ \\ ${ }^{1}$ Center for Ocean Observing Leadership, Department of Marine and Coastal Sciences, Rutgers University, New Brunswick, \\ New Jersey 08901, USA \\ ${ }^{2}$ Louisiana Universities Marine Consortium, Chauvin, Louisiana 70344, USA \\ ${ }^{3}$ College of Marine Science, University of South Florida, St. Petersburg, Florida 33701, USA
}

\begin{abstract}
Antarctic krill Euphausia superba is a key species in the Southern Ocean, where its habitat is projected to undergo continued warming and increases in $p \mathrm{CO}_{2}$. Experiments during 2 summer field seasons at Palmer Station, Antarctica, investigated the independent and interactive effects of elevated temperature and $p \mathrm{CO}_{2}$ (decreased $\mathrm{pH}$ ) on feeding, growth, acid-base physiology, metabolic rate, and survival of adult Antarctic krill. Ingestion and clearance rates of chlorophyll were depressed under low $\mathrm{pH}$ (7.7) compared to ambient $\mathrm{pH}$ (8.1) after a $48 \mathrm{~h}$ acclimation period, but this difference disappeared after a $21 \mathrm{~d}$ acclimation. Growth rates were negligible and frequently negative, but were significantly more negative at high $\left(3^{\circ} \mathrm{C},-0.03 \mathrm{~mm}\right.$ $\left.\mathrm{d}^{-1}\right)$ compared to ambient temperature $\left(0^{\circ} \mathrm{C},-0.01 \mathrm{~mm}\right.$ $\mathrm{d}^{-1}$ ) with no effect of $\mathrm{pH}$. Modest elevations in tissue total $\mathrm{CO}_{2}$ and tissue $\mathrm{pH}$ were apparent at low $\mathrm{pH}$ but were short-lived. Metabolic rate increased with temperature but was suppressed at low $\mathrm{pH}$ in smaller but not larger krill. Although effects of elevated temperature and/or decreased $\mathrm{pH}$ were mostly sublethal, mortality was higher at high temperature/low $\mathrm{pH}$ (58\%) compared to ambient temperature/pH or ambient temperature/low pH (>90\%). This study identified 3 dominant patterns: (1) shorter-term effects were primarily pH-dependent; (2) krill compensated for lower $\mathrm{pH}$ relatively quickly; and (3) longer-term effects on krill growth and survival were strongly driven by temperature with little to no $\mathrm{pH}$ effect.
\end{abstract}

KEY WORDS: Antarctic krill · Ocean acidification • Ocean warming · Feeding · Growth · Physiology · Metabolism · Survival

\footnotetext{
*Corresponding author: saba@marine.rutgers.edu
}

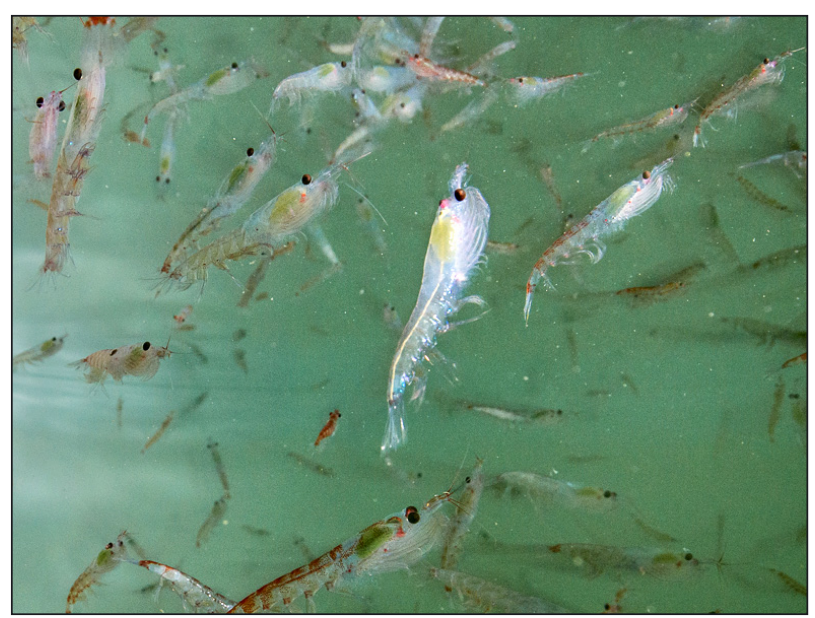

Antarctic krill Euphausia superba, a regional keystone species, inhabit a rapidly warming and acidifying Southern Ocean.

Photo credit: Chris Linder

\section{INTRODUCTION}

Antarctic krill Euphausia superba is a key species in Antarctic food webs (Everson 2000, Atkinson et al. 2004). Over the past $90 \mathrm{yr}$, historical hotspots of postlarval krill abundance have shifted southward from the Southwest Atlantic Sector to the West Antarctic Peninsula (WAP) shelf system (Atkinson et al. 2019). These southward shifts, along with sharp declines in juvenile abundance and recruitment since the 1970s, are attributed to increasing temperatures and winds as well as reductions in sea ice (Atkinson et al. 2019).

(C) The authors 2021. Open Access under Creative Commons by Attribution Licence. Use, distribution and reproduction are unrestricted. Authors and original publication must be credited. 
Continued environmental warming is likely to exacerbate both the decline in krill biomass (Klein et al. 2018) and the southward shift in their distribution.

In addition to continued warming, the Southern Ocean is likely to be one of the first areas affected by ocean acidification. Earlier models projected that undersaturation with respect to aragonite would occur in the Southern Ocean by the end of this century (Orr et al. 2005, McNeil \& Matear 2008). However, a recent study detected much shallower aragonite saturation horizons, indicating that this process is occurring faster than previously projected (Negrete-García et al. 2019). Combined, the projected increases in temperature $\left(+1.1-5.1^{\circ} \mathrm{C}\right)$ and decreases in $\mathrm{pH}$ (up to 0.4 units) for the Antarctic region (RCP8.5; IPCC 2013) may pose a risk to krill.

Antarctic krill inhabit a narrow temperature range south of the Antarctic convergence $\left(-1.8\right.$ to $\left.5.5^{\circ} \mathrm{C}\right)$ (McWhinnie \& Marciniak 1964). Across that range, the metabolic temperature sensitivity of routine metabolism ( $E=0.74$; equivalent to a $Q_{10}$ near 2.8; Tarling 2020) is within the range reported for diverse marine species (Deutsch et al. 2020). Thus, the metabolic rate at the warmer end of this species' range is nearly double that at the colder end. Warmer temperatures also reduce the interval between molting events (intermolt period, IMP) and decrease growth rates for this species (Poleck \& Denys 1982, Buchholz 1991, Atkinson et al. 2006, Brown et al. 2010).

Negative effects of elevated partial pressure of carbon dioxide $\left(p \mathrm{CO}_{2}\right)$ in seawater on Antarctic krill have been observed in early life stages and associated with decreased hatching success and irregular embryonic development (Kawaguchi et al. 2011, 2013). Long-term elevations in energetic costs in response to increased warming and/or $p \mathrm{CO}_{2}$ may eventually impact growth and reproduction (e.g. Wickins 1984, Kurihara et al. 2008, Cooper et al. 2017, McLean et al. 2018). One study of adult E. superba found that rates of chlorophyll ingestion and nutrient excretion were 1.5- to 3-fold higher under elevated $p \mathrm{CO}_{2}$, which could result from, among other possible explanations, increased energetic costs of maintaining internal acid-base equilibria under these conditions (Saba et al. 2012). When provided with a constant supply of food, adult E. superba survival, growth, maturation, lipid biochemistry, and metabolism were resilient during $1 \mathrm{yr}$ of experimental exposure to near-future ocean acidification conditions (Ericson et al. 2018, 2019). These results highlight the importance of food availability to survival and success in a changing ocean (Saba et al. 2012,
Seibel et al. 2012, Sperfeld et al. 2017, Ericson et al. 2019) and suggest that krill may have difficulty meeting increased demands for energy in time periods (e.g. winter) or locations (e.g. northern WAP) with low food availability.

Elevated $p \mathrm{CO}_{2}$ can also impact marine invertebrates by disturbing their acid-base physiology, resulting in hypercapnia $\left(\mathrm{CO}_{2}\right.$-induced acidification of body fluids; reviewed for crustaceans by Whiteley 2011). Some organisms suppress metabolism when seawater $\mathrm{pH}$ is low (Hand 1998, Langenbuch \& Pörtner 2004, Rosa \& Seibel 2008, Maas et al. 2012, Seibel et al. 2012). However, this suppression is typically a response to natural $\mathrm{CO}_{2}$ variability that correlates with periods of resource limitation (e.g. overwintering, low tides, daily migrations into deep hypoxic zones). Alternatively, organisms may compensate for changes in seawater $\mathrm{pH}$ by shifting acid-base and ion equilibria to new steady-state values (reviewed by Baumann 2019, Melzner et al. 2020); such compensation often incurs an energetic cost (Hu et al. 2011, Heuer \& Grosell 2016). Furthermore, physiological oxygen transport systems may be compromised (Pörtner 1990, Pörtner et al. 2004), making them less effective at extracting oxygen $\left(\mathrm{O}_{2}\right)$ and requiring organisms to process more water to obtain sufficient oxygen to meet their metabolic demands. Bridges et al. (1983) found high pH-sensitivity of hemocyanin in E. superba at $-1.5^{\circ} \mathrm{C}$, suggesting that without $\mathrm{pH}$ compensation, elevated $\mathrm{CO}_{2}$ could reduce oxygen transport capacity in these animals. However, Birk et al. (2018) found that extracellular $\mathrm{pH}$ is typically fully compensated, and the effect of $\mathrm{CO}_{2}$ on oxygen-binding affinity is unlikely to produce measurable effects on oxygen consumption rates, even in animals with highly $\mathrm{pH}$-sensitive blood, such as squids and the krill in the present study.

Although the effects of elevated temperature and high $\mathrm{pCO}_{2}$ on Antarctic krill feeding, growth, and physiology have been reviewed (e.g. Flores et al. 2012) or studied separately, their combined impact has not yet been investigated. The combination of multiple stressors may exacerbate responses to changing ocean conditions through antagonistic, additive, or synergistic effects (Breitburg et al. 2015, Kroeker et al. 2017) as evidenced by a meta-analysis of marine taxa that found greater sensitivity to ocean acidification at higher temperatures (Kroeker et al. 2013). The present study explores the independent and interactive effects of elevated temperature and $p \mathrm{CO}_{2}$ on adult E. superba. Specifically, we investigated shorter-term (hours) and longer-term (weeks) 
effects of these climate-related variables on Antarctic krill feeding rates, growth, acid-base status, metabolism, and survival during 2 field seasons at Palmer Station, Antarctica.

\section{MATERIALS AND METHODS}

Multiple experiments were conducted during 2 field seasons, austral summers 2013/2014 and 2014/2015 (hereafter season 2014 and 2015, respectively). These experiments, and their target treatments, are described below and summarized in Table 1. cycle and displayed schooling behavior in the holding tanks at these ambient light levels. Ambient temperature and $\mathrm{pH}$ of the seawater feeding the tanks were selected as our experimental ambient values.

\subsection{Design and summary of experiments}

Two krill feeding experiments and 1 metabolic rate experiment were conducted during 2014 (Table 1). These experiments comprised 3 target treatments: (1) ambient temperature and $\mathrm{pH}\left(0^{\circ} \mathrm{C} / \mathrm{pH}=8.1\right.$; hereafter referred to as 'ambient temperature/ $\left.\mathrm{pH}^{\prime}\right)$; (2) ambient temperature/low $\mathrm{pH}\left(0^{\circ} \mathrm{C} / \mathrm{pH}=7.7\right)$, a $\mathrm{pH}$

\subsection{Collection and husbandry}

In each season, krill were collected near Palmer Station (Anvers Island, Antarctica) during a Long-Term Ecological Research cruise on the ARSV 'Laurence M. Gould' using a $2 \times 2 \mathrm{~m}$ square frame net with $1000 \mu \mathrm{m}$ mesh and a non-filtering codend. Krill were placed in insulated coolers filled with filtered surface seawater and immediately transported to Palmer Station, either via the ARSV 'Laurence $M$. Gould' or small vessels, where they were quickly transferred to holding tanks in the Palmer Station aquarium facility. The time between collection and transport to the station and placement in the tanks was typically $<1 \mathrm{~h}$. Krill were placed into either rectangular (675 l) or round (1900 l) tanks. All tanks were supplied with flow-through unfiltered seawater sourced from Arthur Harbor and circulated at a rate that replaced the volume of the tank at least 3 times per day. The unfiltered seawater allowed krill to feed ad libitum on the natural prey assemblage. Due to the noted lack of natural krill schooling behavior when artificial lighting was on in the aquarium room, no artificial lighting was used in the aquarium room or environmental chambers throughout the holding period and experimental incubations. Windows in the aquarium facility admitted ambient light, so krill were exposed to the seasonal day/night
Table 1. Summary of Antarctic krill experiments, target treatments, and actual conditions measured during 2 field seasons at Palmer Station, Antarctica. Target treatments in bold represent ambient conditions (temperature and/or $\mathrm{pH}$ ). ND: not determined

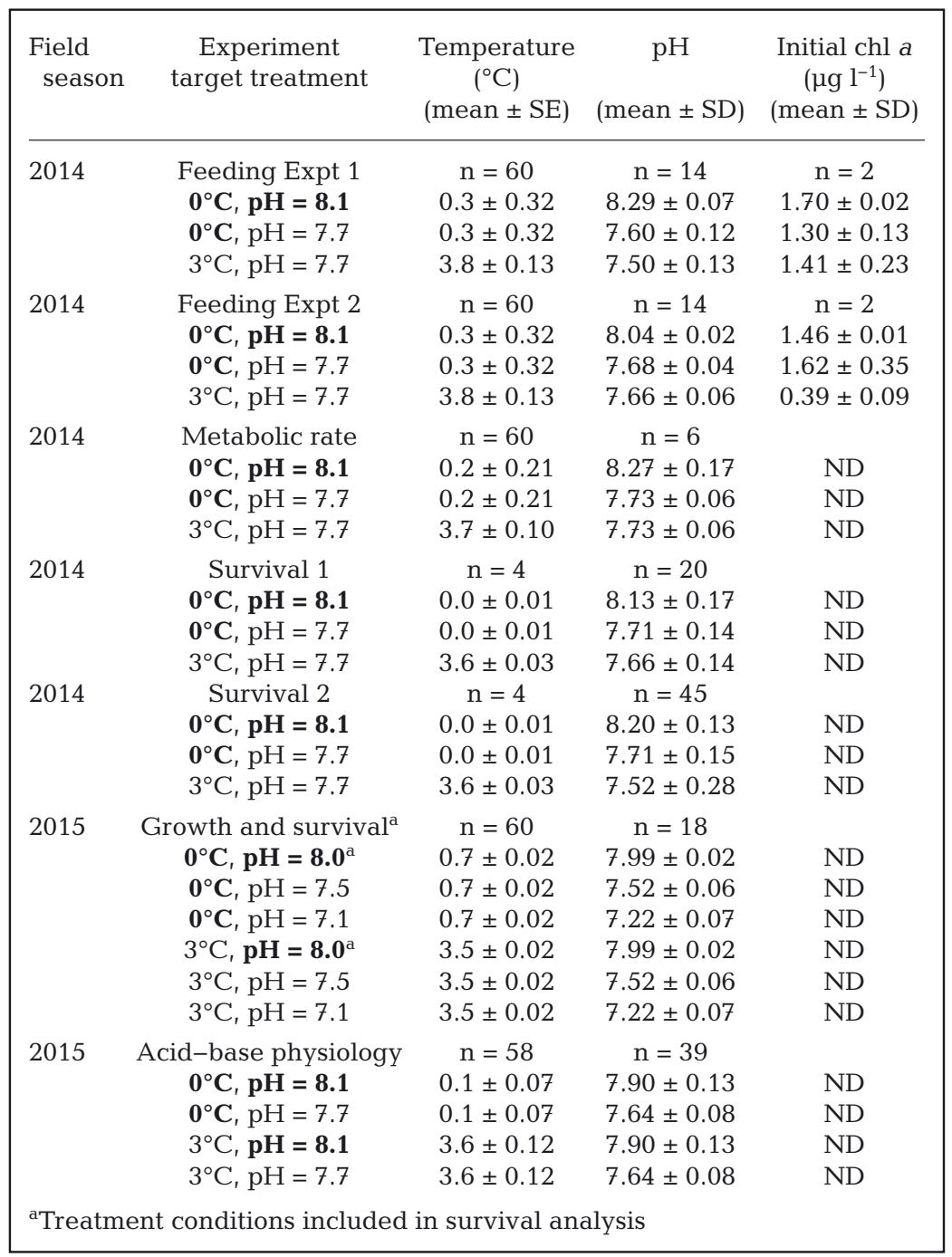


value selected as a drop of up to 0.4 units projected under RCP8.5 (IPCC 2013); and (3) high temperature/low $\mathrm{pH}\left(3^{\circ} \mathrm{C} / \mathrm{pH}=7.7\right)$, temperature selected as the mean projected increase in temperature under RCP8.5 (Bopp et al. 2013, IPCC 2013) (Table 1). Unfortunately, due to logistical constraints during the 2014 field season, specifically the lack of a fourth vessel to equilibrate seawater to treatment conditions, we were unable to conduct the feeding and metabolic rate experiments as a fully crossed factorial design that included a fourth experimental treatment (high temperature $\left(3^{\circ} \mathrm{C}\right) /$ ambient $\left.\mathrm{pH}\right)$.

One growth experiment and 4 acid-base physiology experiments were conducted during 2015 (Table 1). The growth experiment comprised 6 target treatments: ambient and high temperature $\left(0\right.$ and $3^{\circ} \mathrm{C}$, respectively) with $3 \mathrm{pH}$ targets at each temperature: ambient (8.0), 7.5, and 7.1 (Table 1). The acid-base experiments comprised 4 treatments: (1) ambient temperature $/ \mathrm{pH}\left(0^{\circ} \mathrm{C} / \mathrm{pH}=8.1\right)$; (2) ambient temperature/low $\mathrm{pH}\left(0^{\circ} \mathrm{C} / \mathrm{pH}=7.7\right)$; (3) high temperature/ ambient $\mathrm{pH}\left(3^{\circ} \mathrm{C} / \mathrm{pH}=8.1\right)$; and (4) high temperature/low $\mathrm{pH}\left(3^{\circ} \mathrm{C} / \mathrm{pH}=7.7\right)$.

Seawater for incubations was equilibrated to each experimental temperature $\left(0\right.$ and $\left.3^{\circ} \mathrm{C}\right)$ using recirculating systems consisting of an 800 l cylindrical carboy, chiller (Delta Star), and temperature controller. Target temperatures were maintained during incubations in environmental chambers set to either 0 or $3^{\circ} \mathrm{C}$. Jars filled with filtered seawater were placed in each environmental chamber and used to monitor temperature throughout each field season using either daily checks with a standard laboratory thermometer (2014) or HOBO loggers (2015). For elevated $p \mathrm{CO}_{2}$ treatments, pure $\mathrm{CO}_{2}$ gas was injected into the tank via a peristaltic pump fed directly into the inflow of an aquarium pump (Petco, King 160 Powerhead) following methods modified from Jokiel et al. (2014). Target $\mathrm{pH}$ was determined using a standard curve of treatment water $\mathrm{pH}$ with peristaltic pump rate.

Salinity was measured with a benchtop conductivity meter (YSI 3100) calibrated daily with a conduc-

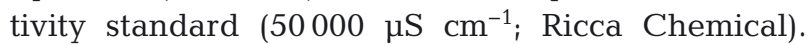
Seawater $\mathrm{pH}$ was determined spectrophotometrically using the indicator dye thymol blue on a Shimadzu spectrophotometer (Zhang \& Byrne 1996, Dickson et al. 2007). Total alkalinity (TA) was determined from $100 \mathrm{ml}$ subsamples with an open-cell, potentiometric titration of seawater (Metrohm 888 Titrando) with $0.1 \mathrm{M} \mathrm{HCl}$ following the potential of a $\mathrm{pH}$ electrode (Dickson et al. 2007). Alkalinity data were processed using Tiamo software (version 2.3). Measurements of $\mathrm{pH}$ and TA were quality controlled using certified reference materials from Andrew Dickson, UCSD Scripps Institute of Oceanography. Water samples collected from each incubation bottle during the feeding experiments were filtered through $200 \mu \mathrm{m}$ mesh onto individual GF/F filters, wrapped in foil, frozen, and analyzed for chlorophyll a (chl a) on a Turner Designs model 10 fluorometer (Parsons et al. 1984).

Krill lengths and wet weights were determined from fresh animals and are reported in the following units throughout this paper. Lengths are expressed as total length (TL, tip of rostrum to tip of telson) in millimeters (mm). Krill TL was calculated from the uropod length (UL) using the following equation generated from our measurements at Palmer Station:

$$
\mathrm{TL}(\mathrm{mm})=4.0677 \times \mathrm{UL}(\mathrm{mm})+12.703
$$

Krill were weighed on a Mettler Toledo XS205 DualRange balance, and units are expressed as wet weight in milligrams (mg). Length-wet weight conversion from the Palmer data was:

$$
\begin{gathered}
\text { Wet weight }(\mathrm{mg})= \\
38.315 \times \mathrm{TL}(\mathrm{mm})-1058.4\left(\mathrm{R}^{2}=0.95\right)
\end{gathered}
$$

\subsection{Feeding experiments}

Two replicate feeding experiments were conducted in 2014, differing in the amount of time krill were acclimated to treatment conditions prior to the start of each $24 \mathrm{~h}$ experiment. Krill used in Experiment 1 (Feeding Expt 1; 24-25 January) and Expt 2 (Feeding Expt 2; 24-25 February) were exposed to treatment conditions for $48 \mathrm{~h}$ and $21 \mathrm{~d}$, respectively, in $19 \mathrm{l}$ plastic buckets with airtight lids at densities of 19 krill per bucket. During acclimation, water was changed every $24 \mathrm{~h}$, whereby $80 \%$ of the water was siphoned out and replaced to minimize excretory and respiratory effects of the animals on treatment conditions. A subset of the siphoned water was used for salinity, $\mathrm{pH}$, and total alkalinity measurements every other day. Due to differences in acclimation time between the 2 experiments, krill were larger in Expt 2 (see Section 3.1).

After acclimation, experimental incubations were conducted using 41 wide-mouth polycarbonate bottles. Each of the 3 treatments in each experiment comprised 14 bottles filled with the appropriate equilibrated seawater. Two bottles per treatment served as $\mathrm{T}_{0}$ controls (no krill added) and were used for an initial suite of samples. Two bottles served as $\mathrm{T}_{\text {final }}(24 \mathrm{~h})$ controls (no krill added), and 1 krill was added to each of the remaining 10 bottles per treat- 
ment $\left(\mathrm{T}_{\text {final }}\right.$ treatments). The $\mathrm{T}_{\text {final }}$ bottles were capped to maintain target $p \mathrm{CO}_{2} / \mathrm{pH}$ and incubated at the appropriate temperature $\left(0^{\circ} \mathrm{C}\right.$ for ambient, $3^{\circ} \mathrm{C}$ for high temperature) for approximately $24 \mathrm{~h}$ before collecting end-point samples. Water samples were collected at $\mathrm{T}_{0}$ and $\mathrm{T}_{\text {final }}$ for $\mathrm{pH}$, total alkalinity, and fluorometric chl a. Clearance and chl a ingestion rates of krill were calculated according to Marin et al. (1986), and expressed as $\mathrm{ml}$ ind.$^{-1} \mathrm{~h}^{-1}$ and $\mu \mathrm{g}$ chlorophyll ind..$^{-1} \mathrm{~d}^{-1}$, respectively.

\subsection{Growth experiment}

Growth data are from 1 long-term experiment conducted in 2015 (Table 1). Krill for this experiment were collected on 1 February by scientists aboard the ARSV 'Laurence M. Gould' and transferred to Palmer Station as previously described. Krill were held in large tanks in the aquarium facility (details in Section 2.1) at ambient temperature and $\mathrm{pH}\left(0^{\circ} \mathrm{C} / \mathrm{pH}=8.0\right)$ for $1 \mathrm{wk}$ prior to the start of the experiment.

This experiment examined krill growth in relation to temperature and $\mathrm{pH}$ over the course of 1 molt cycle (i.e. the krill had to molt twice in order to assess the effect of treatment conditions on growth). To determine the starting point of the molt cycle, adult krill of comparable size were incubated individually in 41 bottles of ambient seawater in the $0^{\circ} \mathrm{C}$ environmental chamber until they molted. Water was changed as previously described and bottles were checked daily for molts. Consistent color in the hepatopancreas indicated that krill were feeding on the natural prey assemblage in the ambient seawater.

When an animal molted in an ambient bottle (the 'initial molt'), indicating the start of a new molt cycle, the individual was transferred to 1 of the 6 treatments comprising this experiment (Tables 1 \& 2). For the high temperature treatments, krill were transferred to ambient temperature treatment water and placed in the $3^{\circ} \mathrm{C}$ environmental room to avoid temperature shock. The date of transfer is the 'start date' and represents the start of exposure to experimental treatment conditions. Start dates span a period of 21 d (Table 2) due to the timing of initial molts. Animals were assigned to treatment groups such that the number in each group was similar at all times, resulting in a range of incubation times for individual krill (1-24 d) with a mean of 13 d (Table 2). Each treatment ultimately comprised 26 individuals. Krill remained in treatment water from their start date until the end of the experiment. Incubation jars remained in environmental chambers except for a brief period each day to change the water and check for molts. Salinity, pH, and total alkalinity were measured frequently for each treatment.

Table 2. Summary information for Antarctic krill growth experiment. Data comprise initial molts at ambient temperature/pH $\left(0^{\circ} \mathrm{C} / \mathrm{pH}=\right.$ 8.0) and second molts from all 6 treatments (see Table 1). Growth rate and intermolt period (IMP) could not be determined for the $0^{\circ} \mathrm{C}$ treatments due to the low number of krill that molted twice, so data for ambient temperature/pH in this study are from initial molts only. -: not applicable

\begin{tabular}{|c|c|c|c|c|c|c|c|c|c|c|c|c|}
\hline $\begin{array}{l}\text { Temp } \\
\left({ }^{\circ} \mathrm{C}\right)\end{array}$ & $\mathrm{pH}$ & $\begin{array}{c}\text { First } \\
\text { animal } \\
\text { start }\end{array}$ & $\begin{array}{c}\text { Last } \\
\text { animal } \\
\text { start }\end{array}$ & $\begin{array}{l}\text { Mean (range) } \\
\text { no. of days } \\
\text { incubated }\end{array}$ & $\begin{array}{l}\text { No. } \\
\text { molted } \\
\text { twice }\end{array}$ & $\begin{array}{l}\text { No. } \\
\text { dead }\end{array}$ & $\begin{array}{l}\text { IMP } \\
\text { (d) }\end{array}$ & $\begin{array}{c}\text { Mean } \\
\text { (range) total } \\
\text { length }(\mathrm{mm})\end{array}$ & $\begin{array}{c}\text { Mean } \\
\text { (range) growth } \\
\text { rate }\left(\mathrm{mm} \mathrm{d}^{-1}\right)\end{array}$ & $\begin{array}{l}\text { \% negative } \\
\text { growth } \\
\text { rates }\end{array}$ & $\begin{array}{l}\text { \% zero } \\
\text { growth } \\
\text { rates }\end{array}$ & $\begin{array}{l}\% \text { positive } \\
\text { growth } \\
\text { rates }\end{array}$ \\
\hline \multicolumn{13}{|c|}{ Initial molts (Holding period in environmental room at ambient conditions) } \\
\hline 0 & 8.0 & 9 Feb & 3 Mar & $\begin{array}{c}11.4 \\
(1-23)\end{array}$ & - & - & 23 & $\begin{array}{c}42.74 \\
(37.55-47.62)\end{array}$ & $\begin{array}{c}-0.01 \\
(-0.15 \text { to }+0.04)\end{array}$ & $\begin{array}{c}56 \\
(\mathrm{n}=85)\end{array}$ & $\begin{array}{c}22 \\
(\mathrm{n}=34)\end{array}$ & $\begin{array}{c}22 \\
(\mathrm{n}=34)\end{array}$ \\
\hline \multicolumn{13}{|c|}{ Second molts (Treatment conditions) } \\
\hline 0 & 8.0 & $11 \mathrm{Feb}$ & 4 Mar & $\begin{array}{c}12 \\
(1-22)\end{array}$ & 1 & 0 & - & $\begin{array}{c}42.74 \\
(37.55-47.62)\end{array}$ & - & - & - & - \\
\hline 0 & 7.5 & $11 \mathrm{Feb}$ & 3 Mar & $\begin{array}{c}12 \\
(3-22)\end{array}$ & 1 & 0 & - & $\begin{array}{c}42.06 \\
(37.17-46.14)\end{array}$ & - & - & - & - \\
\hline 0 & 7.1 & 11 Feb & 3 Mar & $\begin{array}{c}13 \\
(4-22)\end{array}$ & 0 & 2 & - & $\begin{array}{c}41.60 \\
(36.50-45.90)\end{array}$ & - & - & - & - \\
\hline 3 & 8.0 & $11 \mathrm{Feb}$ & 2 Mar & $\begin{array}{c}14 \\
(4-23)\end{array}$ & 7 & 6 & 16 & $\begin{array}{c}40.55 \\
(36.37-46.48)\end{array}$ & $\begin{array}{c}-0.05 \\
(-0.08 \text { to }-0.02)\end{array}$ & $\begin{array}{c}100 \\
(\mathrm{n}=7)\end{array}$ & 0 & 0 \\
\hline 3 & 7.5 & $11 \mathrm{Feb}$ & 2 Mar & $\begin{array}{c}14 \\
(5-23)\end{array}$ & 11 & 1 & 17 & $\begin{array}{c}41.30 \\
(36.64-46.49)\end{array}$ & $\begin{array}{c}-0.03 \\
(-0.09 \text { to }+0.10)\end{array}$ & $\begin{array}{c}73 \\
(\mathrm{n}=8)\end{array}$ & $\begin{array}{c}9 \\
(n=1)\end{array}$ & $\begin{array}{c}18 \\
(\mathrm{n}=2)\end{array}$ \\
\hline 3 & 7.1 & $11 \mathrm{Feb}$ & 3 Mar & $\begin{array}{c}15 \\
(5-24)\end{array}$ & 11 & 1 & 18 & $\begin{array}{c}40.97 \\
(37.44-46.34)\end{array}$ & $\begin{array}{c}-0.03 \\
(-0.07 \text { to }+0.03)\end{array}$ & $\begin{array}{c}73 \\
(\mathrm{n}=8)\end{array}$ & $\begin{array}{c}18 \\
(n=2)\end{array}$ & $\begin{array}{c}9 \\
(\mathrm{n}=1)\end{array}$ \\
\hline
\end{tabular}


The uropods of the molts were measured after each experiment check, and converted to TL using Eq. (1). At the end of the experiment, each krill was weighed, measured (body length, TL, uropod length, telson length), and life history stage (female, male) was recorded along with notes on the condition of the animal. Animals that died during the experiment were processed as above at the time of their death. All measurements were made by 1 author (C.T.S.) to minimize observer bias.

Growth and IMP of euphausiids are commonly measured following the instantaneous growth rate (IGR) protocol (Quetin \& Ross 1991, Nicol et al. 1992, Atkinson et al. 2006, Kawaguchi et al. 2006, Tarling et al. 2006, Shaw et al. 2010 and references therein). This method utilizes short-term incubations (typically 4-5 d for Euphausia superba) of freshly collected krill, where IMP is estimated based on the proportion of animals that molt during the experiment, and growth rate $\left(\mathrm{mm} \mathrm{d}^{-1}\right)$ is calculated by dividing the growth increment (change in length pre-molt to post-molt) by the IMP. IMP may also be measured directly in longterm incubations that maintain krill in captivity over the course of 2 or more molt cycles (Pinchuk \& Hopcroft 2007), although this method is less commonly used due to the experimental effort and potential confounding factors from long-term captivity. In the present study, neither method of estimating IMP was applicable to both initial and second molts. To use direct measurement for initial molters would require a second molt under ambient conditions, which was not available because individuals were transferred to a treatment after their initial molt. To use the IGR method for second molters would require that incubations of all individuals had begun simultaneously, whereas they actually spanned a period of $21 \mathrm{~d}$. As such, IMP for initial molters at ambient temperature/ $\mathrm{pH}$ was estimated following the IGR method and based on the number of molts during the first $4 \mathrm{~d}$ of the incubation. For $3^{\circ} \mathrm{C}$ treatments, IMP was determined directly from the number of days between initial and second molts of krill that molted twice.

\subsection{Survival}

Survival was analyzed as an adjunct to long-term incubation experiments. As experimental protocols often necessitated sacrificing animals at intermediate time points, only 3 experiments were suitable for survival analysis: the 2015 growth experiment (results presented here) and 2 additional experiments from 2014. Other than survival, measurements from these
2014 experiments are not reported in the present study due to too few molts during growth experiments or lack of inter-comparability due to differences in experimental temperatures or other metrics. Survival analysis comprised the following target treatments: (1) ambient temperature $/ \mathrm{pH}\left(0^{\circ} \mathrm{C} / \mathrm{pH}=\right.$ $8.1, \mathrm{n}=52)$; (2) ambient temperature/low $\mathrm{pH}\left(0^{\circ} \mathrm{C}\right.$, $\mathrm{pH}=7.7, \mathrm{n}=52$ ); (3) high temperature/ambient $\mathrm{pH}$ $\left(3^{\circ} \mathrm{C}, \mathrm{pH}=8.0, \mathrm{n}=20\right)$; and (4) high temperature/low $\mathrm{pH}\left(3^{\circ} \mathrm{C}, \mathrm{pH}=7.7, \mathrm{n}=52\right)$. Survivorship was recorded daily over incubation periods of 9-24 d.

\subsection{Acid-base physiology experiments}

Two shorter-term (12-48 h) and 2 longer-term (7-14 d) experiments were conducted to assess the effects of treatment conditions on acid-base balance. Krill were held in 1 of 4 treatments (as described in Section 2.2; Table 1) and acid-base parameters measured at time $=0,1,6,12,24$, and $48 \mathrm{~h}$, and 7 and $14 \mathrm{~d}$. The 7 and $14 \mathrm{~d}$ time points were removed from further analysis due to an insufficient number of measurements. Incubations were conducted in 191 plastic buckets with airtight lids. Buckets were filled with treatment water, stocked at a density of 19 krill per bucket, and placed in environmental chambers set to each experimental temperature (ambient at $0^{\circ} \mathrm{C}$ or high at $3^{\circ} \mathrm{C}$ ). Water was changed every $24 \mathrm{~h}$ to maintain water quality.

At each time point, blood was collected from $\mathrm{n}=$ 5-10 krill using a 20-gauge hypodermic needle for $\mathrm{pH}$ and lactate measurements. Blood was collected in gastight Hamilton syringes and transferred to Eppendorf tubes for immediate $\mathrm{pH}$ measurement. $\mathrm{pH}$ was measured in the absence of air. Total time required for collection from multiple krill for each $\mathrm{pH}$ and lactate measurement was 5-10 min. Blood samples were pooled to measure: (1) blood pH using a temperaturecontrolled pH microelectrode (Microelectrodes) ( $\mathrm{n}=2$ pooled samples per treatment per time point; calibrated using certified reference materials); and (2) blood lactate with a handheld lactate analyzer (Roche Accutrend) ( $\mathrm{n}=2$ pooled samples per treatment per time point). Abdominal segments were excised and flash frozen for tissue analysis. For determination of tissue total $\mathrm{CO}_{2}\left(\mathrm{TCO}_{2}\right)$ and tissue $\mathrm{pH}$, tissue from each individual was weighed and homogenized in $500 \mu \mathrm{l}$ homogenate buffer containing $150 \mathrm{mmol}$ potassium fluoride and $5 \mathrm{mmol}$ nitrilotriacetic acid (Pörtner et al. 1990). Homogenate (75 $\mu \mathrm{l})$ was injected into a Corning 965 Total $\mathrm{CO}_{2}$ analyzer to determine $\mathrm{TCO}_{2}$ ( $\mathrm{n}=4-5$ ind. treatment ${ }^{-1}$ at each time point). The re- 
maining homogenate was used to measure tissue $\mathrm{pH}$ ( $\mathrm{n}=5-10$ ind. treatment $^{-1}$ at each time point) using a $\mathrm{pH}$ microelectrode (as above) calibrated to a $\mathrm{pH} 7.11$ standard. Tissue lactate $\left(\mathrm{n}=3-5\right.$ ind. treatment ${ }^{-1}$ at each time point) was measured by homogenizing tissue at 1:1 in deionized water spiked with 2 mM lactate, using $3 \mathrm{ml}$ glass homogenizers on ice. Supernatant was then measured for lactate as above.

\subsection{Metabolic rate experiment}

Metabolic rate was measured using end-point respirometry. Krill were held under treatment conditions ( $\mathrm{n}=40$ ind. treatment ${ }^{-1}$, Table 1) for $24 \mathrm{~h}$ in $19 \mathrm{l}$ plastic buckets. Biological oxygen demand (BOD) bottles $(300 \mathrm{ml})$ were then filled with $2 \mu \mathrm{m}$ filtered treatment water, and 1 krill was placed into each bottle. Each treatment included 1 control bottle (containing treatment water but no krill) to correct for residual microbial respiration. All bottles were incubated in the dark for $6 \mathrm{~h}$ in a water bath in an environmental chamber held at the experimental temperature (ambient at $0^{\circ} \mathrm{C}$ or high at $3^{\circ} \mathrm{C}$ ). At the end of the incubation period, dissolved oxygen in each bottle was measured using an oxygen electrode (Strathkelvin Instruments). Respiration rates (in $\mu$ mol $\mathrm{O}_{2} \mathrm{~g}^{-1} \mathrm{~h}^{-1}$ ) were calculated as the difference between the dissolved oxygen concentration in the control bottle (no krill) and the final dissolved oxygen concentration in each treatment bottle standardized to the body mass in wet weight of each individual krill. Oxygen never declined below $75 \%$ saturation, which is well above the critical $p \mathrm{O}_{2}$ for the species (Torres et al. 1994).

\subsection{Statistics}

Significance among treatment conditions in the feeding and growth experiments was determined using the 'Statistics and machine learning toolbox' in Matlab (version 2019a). Clearance and ingestion rate data were tested for normal distributions (ShapiroWilk test), normalized using rank transformation, and compared within and among experiments and treatments using multi-way ANOVA and TukeyKramer post hoc tests ( $\mathrm{p}<0.05)$. Due to the non-normal distribution and variable sample sizes, comparisons of growth rates among treatments required a non-parametric Kruskal-Wallis test ( $\mathrm{p}<0.05)$, and a Dunn post hoc test with no adjustment ( $\mathrm{p}<0.05$ ).

For the survival, acid-base physiology, and metabolic rate analyses, there were no significant differ- ences in survival among experiments within each experimental treatment (log-rank test); therefore, data from all 3 experiments were combined for analysis. Curves of combined survival data were compared using the log-rank test for statistical significance in Graphpad Prism 7.0. Differences were considered significant at $p<0.05$. Acid-base parameters were log transformed and analyzed as a 3-way factorial design using PROC GLIMMIX in SAS 9.4 with temperature, $\mathrm{CO}_{2}$, and time as fixed effects. Fixed effects were specified as classification variables using levelization through the CLASS statement in SAS and the generalized linear model fit by the method of maximum likelihood. The KenwoodRogers method of degrees of freedom was used along with an autoregressive covariance structure $(\mathrm{TYPE}=\mathrm{AR}[1])$ that best fit the time series. The 'SLICE' option within GLIMMIX was used to discern differences among treatment groups within each time point. Time point $t=0$ was eliminated from statistical analysis due to a lack of measurements for all 4 treatment groups. The slope of the relationship between metabolic rate and body mass was compared among treatment groups using ANCOVA in SAS 9.4.

\section{RESULTS}

Experimental temperature and $\mathrm{pH}$ measured during all experiments, and initial chl a concentrations in the 2 feeding experiments, are summarized in Table 1 . In addition, mean $\pm \mathrm{SD} \mathrm{pH}$ values measured at water changes during the $21 \mathrm{~d}$ acclimation period for Feeding Expt 2 were $8.24 \pm 0.13,7.78 \pm 0.05$, and $7.74 \pm 0.03$ for the ambient temperature/pH, ambient temperature/low $\mathrm{pH}$, and high temperature/low $\mathrm{pH}$ conditions, respectively ( $\mathrm{n}=11$ per treatment condition). Raw data collected during the experimental incubations and water changes, including additional carbonate chemistry data, are available from the Biological \& Chemical Oceanography Data Management Office (BCO-DMO) data repository: https:// www.bco-dmo.org/project/721363.

\subsection{Feeding experiments}

Krill in Expt 1 had a mean weight of $210 \mathrm{mg}$ and mean $\pm \mathrm{SD}$ length of $33.1 \pm 1.3 \mathrm{~mm}(\mathrm{n}=30)$. Krill in Expt 2 were larger due to growth during the longer acclimation period $(21 \mathrm{~d})$, with a mean weight of $447 \mathrm{mg}$ and mean length of $39.3 \pm 2.0 \mathrm{~mm}(\mathrm{n}=30)$. 
Clearance and ingestion rates were significantly lower under low $\mathrm{pH}$ compared to ambient when acclimated to experimental treatments for $48 \mathrm{~h}$ (Expt 1, Fig. 1; ANOVA, Tukey-Kramer post hoc, p < 0.0001). However, there was no difference between the ambient temperature/low $\mathrm{pH}$ and the high temperature/low $\mathrm{pH}$ treatments (Fig. 1, Expt 1). In Expt 2, where krill were acclimated to treatment conditions for $21 \mathrm{~d}$, there were no differences in clearance and ingestion rates between ambient temperature/ $\mathrm{pH}$ and ambient temperature/low $\mathrm{pH}$ treatments. However, rates were lower in the high temperature/low $\mathrm{pH}$ treatment (Fig. 1; ANOVA, TukeyKramer post hoc, p < 0.0001). Both clearance and ingestion rates in ambient temperature/pH conditions were lower in Expt 2 compared to Expt 1 (ANOVA, Tukey-Kramer post hoc, p < 0.0001). The mean clearance rates in ambient temperature/pH conditions for Expt 1 and Expt 2 were 370 and $196 \mathrm{ml}$ ind. ${ }^{-1} \mathrm{~h}^{-1}$, respectively. The mean ingestion rates in Expts 1 and 2 were 15.1 and $6.9 \mu \mathrm{g}$ chlorophyll ind. $.^{-1} \mathrm{~d} .^{-1}$, respectively.

The initial concentration of chl $a$ in the high temperature/low $\mathrm{pH}$ treatment in Expt 2 (mean $=0.39 \mu \mathrm{g} \mathrm{l}^{-1}$, Table 1) was $\sim 75 \%$ lower than those concentrations measured in all other treatments in both Expts 1 and 2 (means 1.30-1.70 $\mathrm{g} \mathrm{l}^{-1}$ ). Additionally, differential changes in chlorophyll over time $\left(\mathrm{T}_{0}\right.$ to $\mathrm{T}_{\text {final }}$ ) occurred in the controls (no krill added). These changes were minimal in the ambient temperature/pH condition $(+7$ and $-7 \%$ in Expts 1 and 2, respectively), but were highly negative under ambient temperature/low pH (-66 and -37\% in Expts 1 and 2, respectively) and high temperature/low $\mathrm{pH}$ ( -34 and $-32 \%$ in Expts 1 and 2, respectively).

\subsection{Growth experiment}

Krill in the growth experiment were of similar sizes (mean $\pm \mathrm{SD}$ length $=$ $39.4 \pm 1.5 \mathrm{~mm}$, mean weight $=451 \mathrm{mg}$; $\mathrm{n}=181 ;$ Table 2). There were too few second molts ( $\mathrm{n}=3$ total) in the 3 ambient temperature treatments $\left(0^{\circ} \mathrm{C}\right)$ to determine separate growth rates or IMPs for these treatments (Table 2). However, growth rates from the initial molts serve as a dataset for ambient
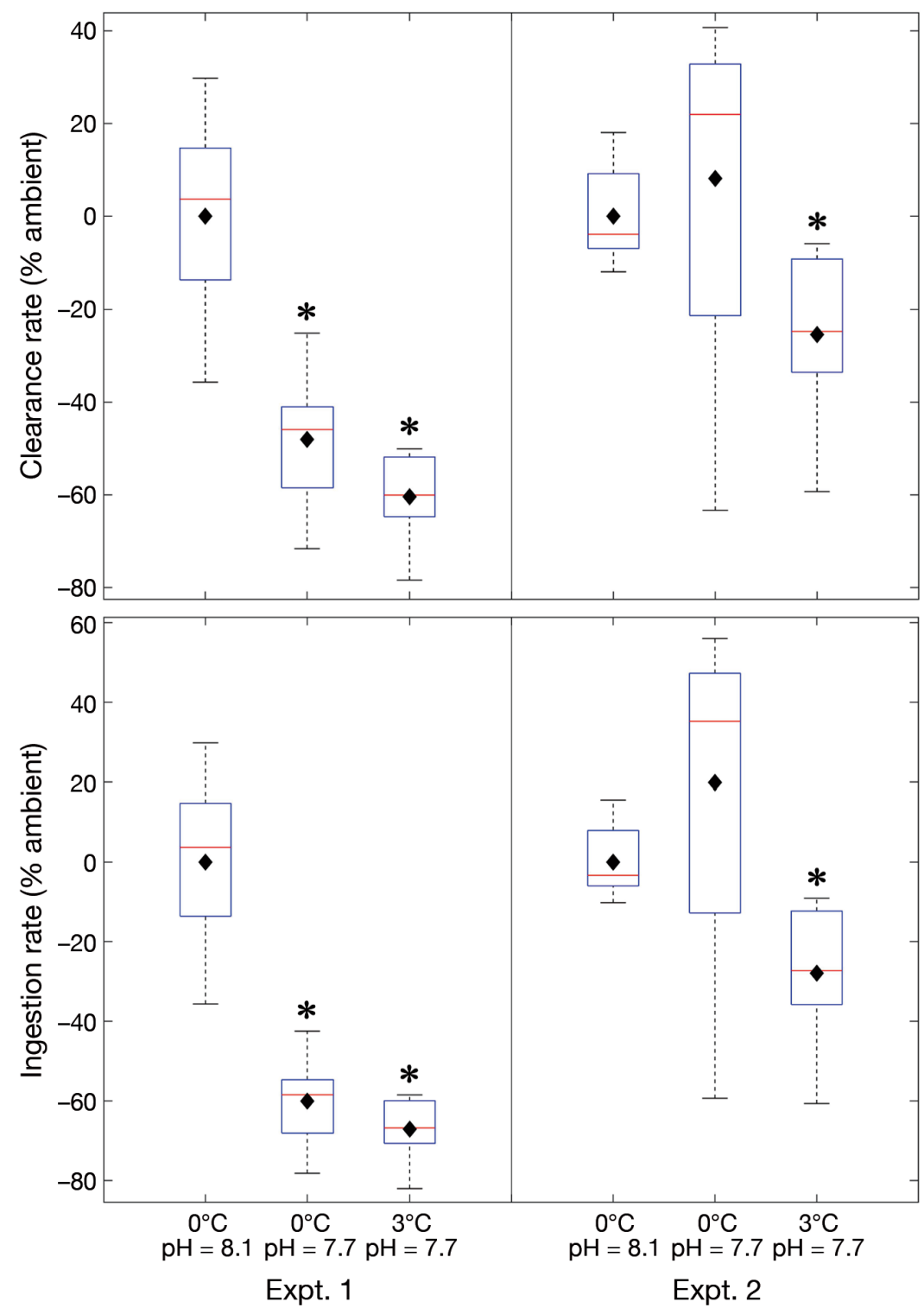

Fig. 1. Antarctic krill clearance rates (top) and ingestion rates (bottom) on chlorophyll a expressed as \% ambient during Expts 1 and 2. Temperature = $0^{\circ} \mathrm{C}$ and $\mathrm{pH}=8.1$ represents ambient conditions. The mean clearance rates in ambient temperature and $\mathrm{pH}$ conditions for Expts 1 and 2 were 370 and $196 \mathrm{ml}$ ind.$^{-1} \mathrm{~h}^{-1}$, and the mean ingestion rates in ambient temperature and $\mathrm{pH}$ conditions were 15.1 and $6.9 \mu \mathrm{g}$ chlorophyll ind. ${ }^{-1} \mathrm{~d}^{-1}$, respectively. These means were set to zero here, and the 2 other treatments in each experiment (ambient temperature/low $\mathrm{pH}, 0^{\circ} \mathrm{C} / \mathrm{pH}=7.7$; high temperature/low $\mathrm{pH}, 3^{\circ} \mathrm{C} / \mathrm{pH}=7.7$ ) are expressed as \% ambient rates. The box limits extend from the lower to upper quartiles, with a line at the median and a diamond at the mean. Whiskers show the range of the data. Significantly lower clearance or ingestion values within an experiment are denoted by * (multi-way ANOVA, Tukey-Kramer post hoc tests, $\mathrm{p}<0.0001$ ) 


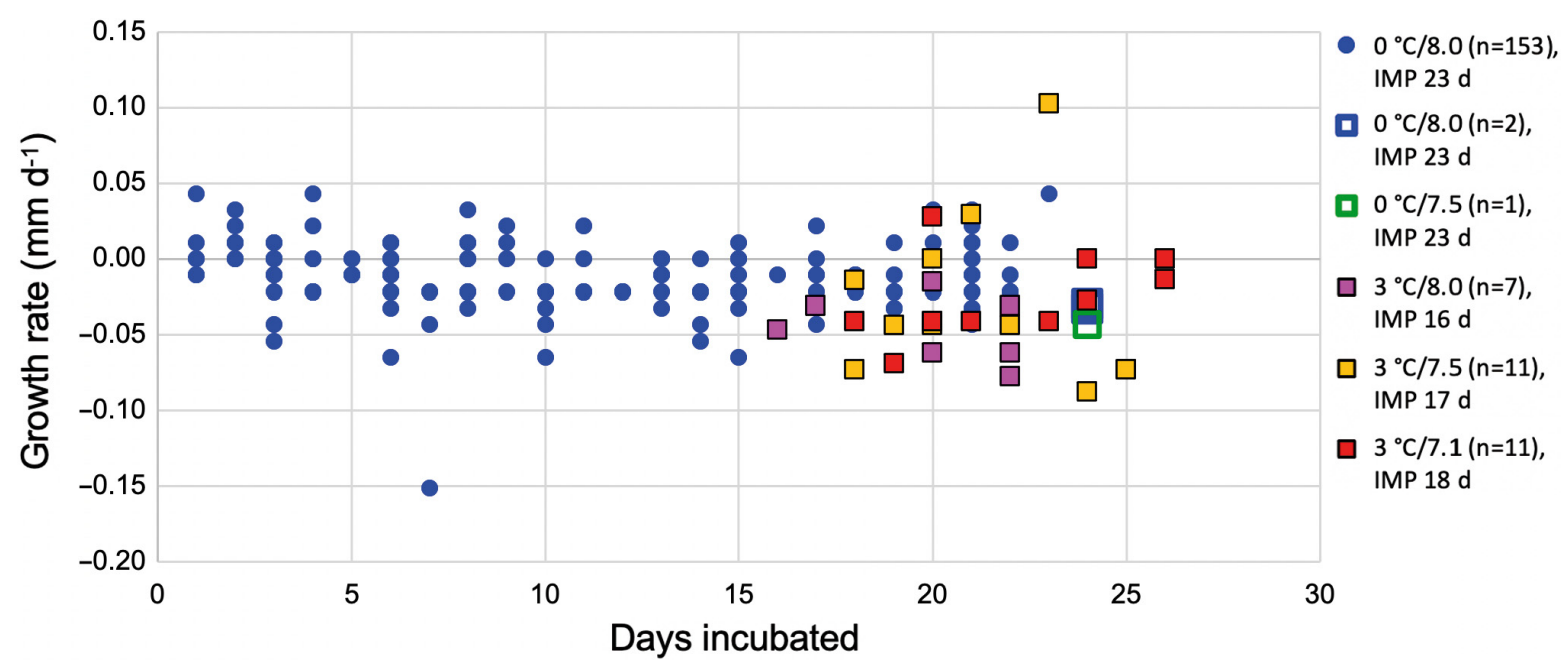

Fig. 2. Growth rates of individual Antarctic krill shown by number of days incubated prior to molting. Blue circles represent growth rates from initial molts (ambient temperature/pH). Squares represent growth after exposure to treatment conditions over 1 molt cycle. Key shows treatment conditions, number of data points, and intermolt period (IMP) for each treatment. Note that axes do not intersect at zero

temperature/pH since these rates were obtained under the same conditions as the ambient temperature $/ \mathrm{pH}$ treatment $\left(0^{\circ} \mathrm{C}, \mathrm{pH}=8.0\right)$. Thus, data from this experiment comprise growth rates and IMPs from initial molts at ambient temperature $/ \mathrm{pH}$ and from second molts at high temperature treatments for $\mathrm{pH}=8.0$ (ambient), 7.5, and 7.1 (Table 2).

Because IMP is strongly tied to temperature (e.g. Poleck \& Denys 1982, Buchholz 1991, Atkinson et al. 2006, Kawaguchi et al. 2006, Tarling et al. 2006, Wiedenmann et al. 2008, Brown et al. 2010), most of the krill that molted twice during the experiment were from the high temperature treatments. Using initial molts to represent ambient temperature/pH conditions, the total number of molts was $\mathrm{n}=153$, with an IMP of $23 \mathrm{~d}$. In the high temperature treatments, krill exposed to ambient $\mathrm{pH}$ had $\mathrm{n}=7$ molts and IMP of $16 \mathrm{~d}$, krill in $\mathrm{pH}=7.5$ had $\mathrm{n}=11$ molts and IMP of $17 \mathrm{~d}$, and krill in $\mathrm{pH}=7.1$ had $\mathrm{n}=11$ molts and IMP of $18 \mathrm{~d}$. The IMP was significantly shorter at high temperature (mean among the $3 \mathrm{pH}$ treatments $=17 \mathrm{~d}$ ) compared to ambient ( 23 d) but was unaffected by $\mathrm{pH}$ (Fig. 2). The number of days incubated and TLs of krill (average and range) were similar among treatments (Table 2).

Individual krill growth rates were negligible, frequently negative, and generally ranged between 0 and $-0.05 \mathrm{~mm} \mathrm{~d}^{-1}$ (Fig. 2). Growth rates at ambient temperature/pH were significantly higher than in the 3 high temperature treatments, but there were no significant differences among the $3 \mathrm{pH}$ treatments at high temperature (Fig. 3; Kruskal-Wallis, Dunn post hoc tests, $\mathrm{p}<$ 0.05). At ambient temperature, the average growth rate was $-0.01 \mathrm{~mm} \mathrm{~d}^{-1}$. This rate was the same whether averaging all initial growth rates $(n=153)$ or just the initial growth rates of the krill that subsequently molted again in one of the treatments $(\mathrm{n}=$

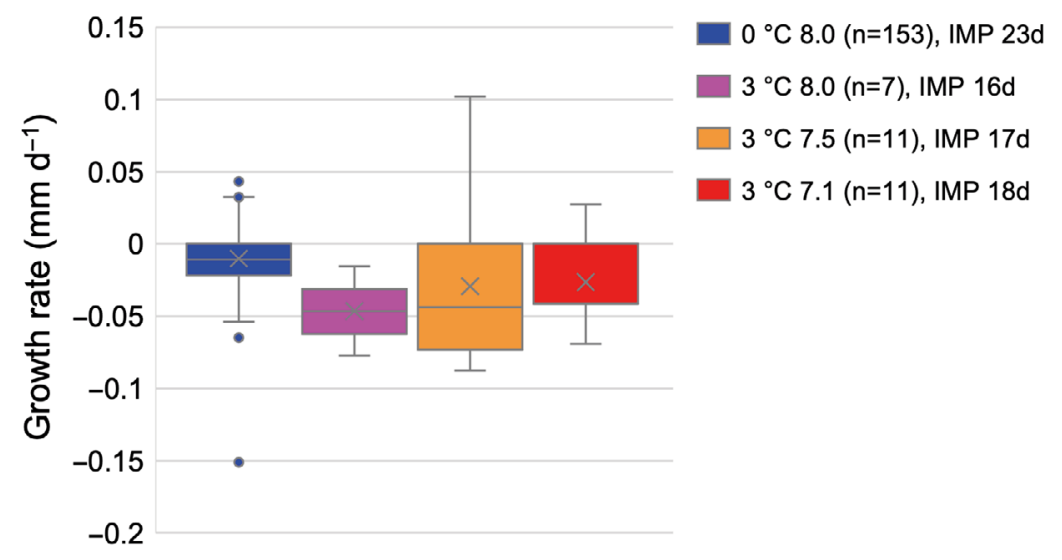

Fig. 3. Growth rates of Antarctic krill from initial molts under ambient conditions $\left(0^{\circ} \mathrm{C}, \mathrm{pH} 8.0\right)$ and from second molts in high temperature $\left(3^{\circ} \mathrm{C}\right)$ treatments. The color key shows treatment conditions, number of data points, and intermolt period (IMP) for each treatment. The box limits extend from the lower to upper quartiles, with a line at the median and an X at the mean. Median = lower quartile in the high temperature/pH $=7.1$ treatment. Whiskers show the range of the data. Blue dots represent outliers present in the ambient temperature/ $\mathrm{pH}$ treatment 
32). Average growth rate at high temperature $(n=29$ total among all treatments) was $-0.03 \mathrm{~mm} \mathrm{~d}^{-1}$. The growth rates of the few individuals ( $\mathrm{n}=3$ total) that molted twice in the ambient temperature/low $\mathrm{pH}$ $(\mathrm{pH}=7.5$ or 7.1$)$ treatments were similar to growth rates in the high temperature treatments (Fig. 2). The overall average growth rate for all individuals that molted twice, in ambient and high temperature treatments combined, was $-0.04 \mathrm{~mm} \mathrm{~d}^{-1}$.

\subsection{Survival}

Krill analyzed for survival had a mean \pm SD weight of $618 \pm 208 \mathrm{mg}$ and mean length of $40.88 \pm 2.5 \mathrm{~mm}$. Survival ranged from 58 to $98 \%$, with significant differences among treatment groups $(p=0.001$; Fig. 4). There was no difference in survival between krill held at ambient temperature/pH or ambient temperature/low pH (90 and $98 \%$, respectively). However, mortality was higher at high temperature/low $\mathrm{pH}$ $(58 \%)$ than at ambient temperature/pH $(\mathrm{p}=0.02)$. Additionally, there was an indication $(\mathrm{p}=0.08)$ of slightly higher mortality at high temperature/ambient $\mathrm{pH}(67 \%)$ than at ambient temperature/pH, due solely to temperature. However, only 1 of the 3 trials analyzed for survival included a high temperature/ ambient $\mathrm{pH}$ treatment group (2015 growth experiment), resulting in a smaller sample size $(n=20)$ than the other groups ( $\mathrm{n}=52$ each). Further, in the 2015 growth experiment, anomalous mortality $(\mathrm{n}=6)$ occurred in the high temperature/ambient $\mathrm{pH}$ treat-

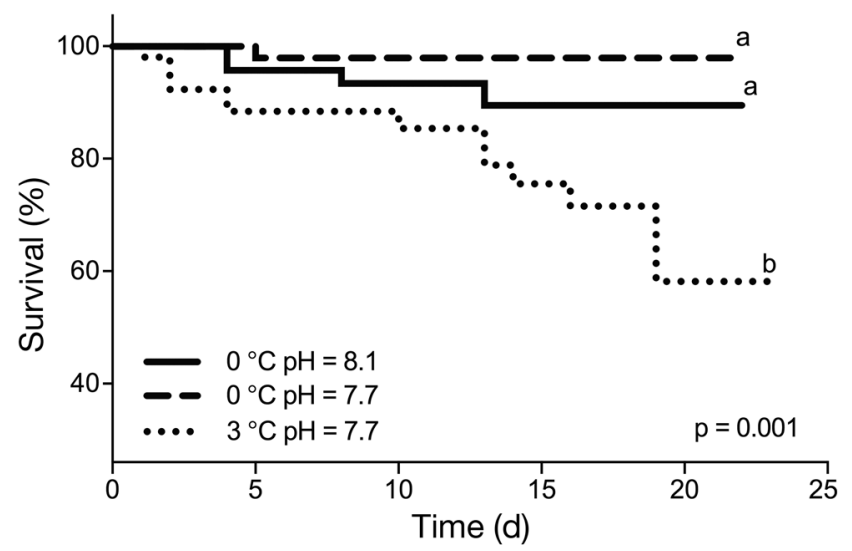

Fig. 4. Survival of Antarctic krill at various levels of experimental temperature and $\mathrm{pH}$. Survival curves with different letters are significantly different $(p<0.05)$. Ambient temperature and $\mathrm{pH}$ conditions are $0^{\circ} \mathrm{C} / \mathrm{pH}=8.1$. Survival was also assessed in individuals at $3^{\circ} \mathrm{C} / \mathrm{pH}=8.0$. Due to differences in sample size, this group is not included here but all comparisons can be found in Section 3 ment. The low mortality at high temperature in other treatments (Table 2) suggests that this mortality was unrelated to treatment conditions (discussed further in Section 4.2). Therefore, although the trend aligns with what might be expected, results for survival at high temperature/ambient $\mathrm{pH}$ are preliminary, and this group was omitted from Fig. 4.

\subsection{Acid-base physiology experiments}

Krill analyzed in these experiments had a mean \pm SD weight of $803 \pm 154 \mathrm{mg}$ (equivalent length $48 \mathrm{~mm}$ ). Full acid-base variables and statistical analyses are reported in Table S1 in the Supplement at www.intres.com/articles/suppl/m665p001_supp.pdf. Tissue $\mathrm{TCO}_{2}$ was highly variable both within and across treatments and time, ranging from a mean of $6.41 \pm$ 3.08 to $18.84 \pm 3.94 \mathrm{mmol} \mathrm{kg}^{-1}$ (Fig. 5A). Environmental $p \mathrm{CO}_{2}$ had a significant effect on tissue $\mathrm{TCO}_{2}$, which was higher under low compared to ambient $\mathrm{pH}$ (Fig. 6B). Time also had a significant effect on $\mathrm{TCO}_{2}$, which generally increased through $12 \mathrm{~h}$ in all treatments, then declined by $48 \mathrm{~h}$ (Fig. 6C). Tissue $\mathrm{pH}$ ranged from a mean $\pm \mathrm{SD}$ of $7.14 \pm 0.03$ to $7.30 \pm$ 0.08 (Fig. 5B) and showed an effect of time similar to that of $\mathrm{TCO}_{2}$, with higher tissue $\mathrm{pH}$ at $6 \mathrm{~h}$ compared to shorter and longer exposures regardless of treatment (Fig. 6F). Tissue pH was also higher under low compared to ambient $\mathrm{pH}$ in krill held at high temperature, although this acid-base disturbance was transient with a return to baseline by $24 \mathrm{~h}$ (Fig. 5B). Tissue lactate was low, ranging from $0.0 \pm 0.00$ to $1.6 \pm$ $1.82 \mathrm{mmol} \mathrm{kg}^{-1}$ (Table S1), and exhibited no change with temperature, $\mathrm{pH}$, or time.

Blood $\mathrm{pH}$ ranged from $8.11 \pm 0.16$ to $8.21 \pm 0.04$ (Fig. 5C). There was no effect of temperature or $\mathrm{pH}$ on blood pH. Blood lactate ranged from 0.00 to $4.5 \pm$ $1.70 \mathrm{mmol} \mathrm{l}^{-1}$ (Fig. 5D) and declined from a high at $1-6 \mathrm{~h}$ to a low at $24-48 \mathrm{~h}$ (Fig. $6 \mathrm{~L}$ ).

\subsection{Metabolic rate experiment}

Metabolic rate was determined across 2 size ranges of adult krill, designated as smaller (116-294 $\mathrm{mg}, 31-35 \mathrm{~mm}$ ) and larger (490-953 mg, 40-52 mm). Mass-specific oxygen consumption rates per gram wet weight $\left(\mathrm{MO}_{2} ; \mu \mathrm{mol} \mathrm{O}_{2} \mathrm{~g}^{-1} \mathrm{~h}^{-1}\right)$ declined significantly with body mass $(\mathrm{M})$ in each treatment according to $\mathrm{MO}_{2}=a \mathrm{M}^{b}$, where $a$ is a normalization constant and $b$ is the scaling coefficient describing the slope of the relationship (at ambient temperature/ 

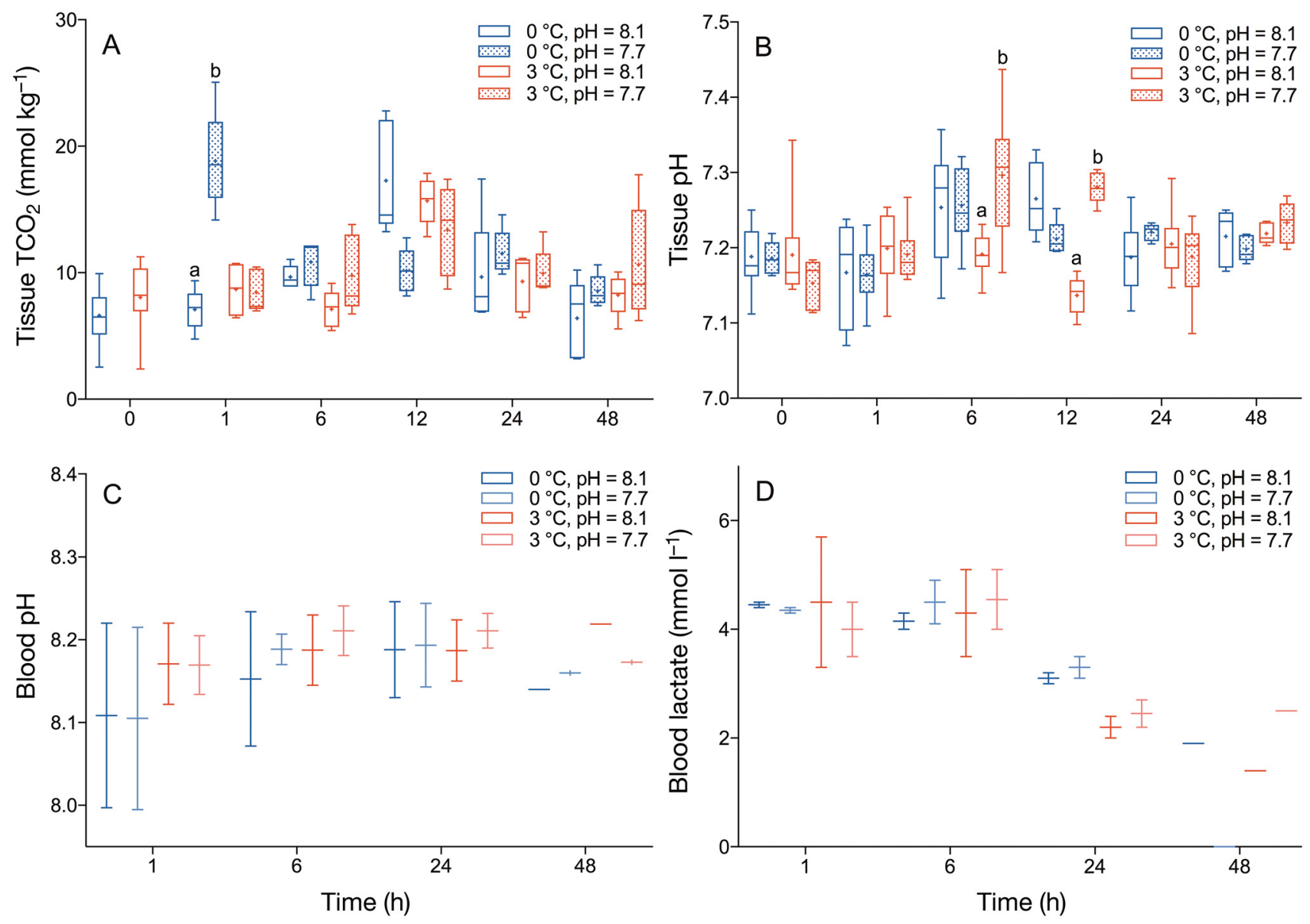

Fig. 5. Acid-base physiology of Antarctic krill at various levels of experimental temperature and pH. Included are (A) tissue total $\mathrm{CO}_{2}\left(\mathrm{TCO}_{2} ; \mathrm{mmol} \mathrm{kg}^{-1}\right)$, (B) tissue $\mathrm{pH},(\mathrm{C})$ blood $\mathrm{pH}$, and (D) blood lactate $\left(\mathrm{mmol} \mathrm{l}^{-1}\right)$ by treatment group and time. Ambient temperature and $\mathrm{pH}$ conditions are $0^{\circ} \mathrm{C} / \mathrm{pH}=8.1$. $(\mathrm{A}, \mathrm{B})$ The box limits extend from the lower to upper quartiles, with a line at the median and $\mathrm{a}+$ symbol at the mean. Whiskers show the range of the data. $(\mathrm{C}, \mathrm{D})$ Whiskers show the range of the data with a line at the median. Significant differences between groups within a time point and temperature treatment are denoted by different letters $(\mathrm{p}<0.05)$

$\mathrm{pH}, \mathrm{MO}_{2}=2.8923 \mathrm{M}^{-0.308}$; at ambient temperature/ low $\mathrm{pH}, \mathrm{MO}_{2}=2.9221 \mathrm{M}^{-0.125}$; and at high temperature/low $\left.\mathrm{pH}, \mathrm{MO}_{2}=3.5036 \mathrm{M}^{-0.407}\right)$. The scaling coefficients were significantly different for each treatment (Fig. 7; ANCOVA, p < 0.0001). At ambient temperature, larger krill exhibited similar oxygen consumption rates regardless of $\mathrm{pH}$ treatment (mean $\pm \mathrm{SD}=3.2 \pm 0.6 \mu \mathrm{mol} \mathrm{O} \mathrm{O}^{-1} \mathrm{~h}^{-1}$ ). However, rates diverged in smaller krill, with higher rates at ambient $\mathrm{pH}\left(5.0 \pm 1.5 \mu \mathrm{mol} \mathrm{O} \mathrm{O}^{-1} \mathrm{~h}^{-1}\right)$ compared to low $\mathrm{pH}$ $\left(3.7 \pm 1.0 \mu \mathrm{mol} \mathrm{O} \mathrm{O}_{2} \mathrm{~g}^{-1} \mathrm{~h}^{-1}\right)$. At high temperature, metabolic rates were higher across the full size range $\left(4.2 \pm 0.8\right.$ and $7.2 \pm 2.4 \mu \mathrm{mol} \mathrm{O} \mathrm{O}^{-1} \mathrm{~h}^{-1}$ in larger and smaller krill, respectively), and the scaling coefficient was significantly higher compared to either of the ambient temperature treatments, indicating a greater sensitivity of metabolic rate to body mass (Fig. 7). In the low $\mathrm{pH}$ treatments, the effect of tem- perature appeared greater for smaller, compared to larger, krill.

\section{DISCUSSION}

This study, which is the first to examine Antarctic krill feeding, growth, and physiological responses under combined warming and ocean acidification conditions, supports 3 dominant conclusions. (1) High $p \mathrm{CO}_{2}$ had a slight effect on feeding rates, metabolic rates, and acid-base balance in the short term, with greater effects on smaller-sized krill at high temperature. (2) Krill have the ability to compensate for lower $\mathrm{pH}$ within hours to days, as observed in the feeding and acid-base experiments. (3) Longer-term effects on krill growth and survival were strongly driven by temperature, with little to no effect from reduced $\mathrm{pH}$. 

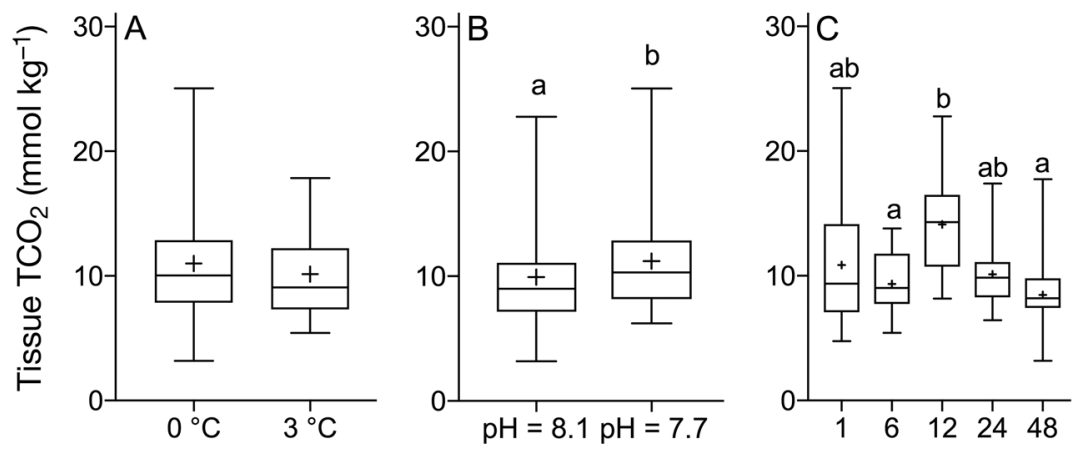

mostly within the range of ingestion rates previously reported for Euphausia superba in the summer (50-445 $\mu \mathrm{g}$ C krill ${ }^{-1} \mathrm{~d}^{-1}$, Perissinotto et al. 1997; 129-447 $\mu \mathrm{g} \mathrm{C} \mathrm{krill}{ }^{-1} \mathrm{~d}^{-1}$, Bernard et al. 2012). Ingestion rates above and below those rates reported in previous studies occurred under ambient temperature/pH conditions in Expt 1 (610-1231 $\mu \mathrm{g} \mathrm{C} \mathrm{krill}{ }^{-1} \mathrm{~d}^{-1}$; mean = $948 \mu \mathrm{g} \mathrm{C} \mathrm{krill}{ }^{-1} \mathrm{~d}^{-1}$ ) and in the high temperature/low $\mathrm{pH}$ treatment in Expt $2\left(0-74 \mu \mathrm{g} \mathrm{C} \mathrm{krill}^{-1} \mathrm{~d}^{-1}\right.$; mean $=$ $22 \mu \mathrm{g} \mathrm{C} \mathrm{krill}{ }^{-1} \mathrm{~d}^{-1}$; see below), respectively. Despite initial chlorophyll concentrations nearly $50 \%$ lower in the present study than those concentrations observed by Saba et al. (2012), ingestion rates were higher overall in the present study compared to the former (Saba et al. 2012; 0-154 $\mu \mathrm{g} \mathrm{C}$ $\mathrm{krill}^{-1} \mathrm{~d}^{-1}$, mean $=51 \mu \mathrm{g} \mathrm{C} \mathrm{krill}{ }^{-1} \mathrm{~d}^{-1}$ ). Phytoplankton community composition was not analyzed in the present study; however, despite the lower chlorophyll concentration, it is possible that the food quality (i.e. phytoplankton species and cell size) in the present study was more favorable compared to Saba et al. (2012), when phytoplankton composition was dominated by small cryptophytes that krill cannot feed on efficiently (Quetin \& Ross 1985). The krill in the present study were collected farther north in the WAP (near Palmer Station) and were smaller adults (Expts 1 and 2 combined mean length $=36.2 \mathrm{~mm}$ ) compared to krill in the study by Saba et al. (2012; mean $=46 \mathrm{~mm})$, so differences in feeding rates between these studies could result from differences in size, maturity stage, or even physiological state.

A recent review found that ingestion rates of arthropods (including krill) were highly variable in response to ocean acidification conditions (Cle-

\subsection{Feeding processes}

Ingestion rates in the present study (mean $=436 \mu \mathrm{g}$ C krill ${ }^{-1} \mathrm{~d}^{-1}$; using carbon:chlorophyll conversion of 63:1; Ducklow et al. 1993, Bernard et al. 2012) were ments \& Darrow 2018). Indeed, even E. superba ingestion rates with respect to $\mathrm{pH}$ from the present study differ from those rates reported by Saba et al. (2012). Ingestion rates in the present study were suppressed at ambient temperature/low pH (Expt 1) and 


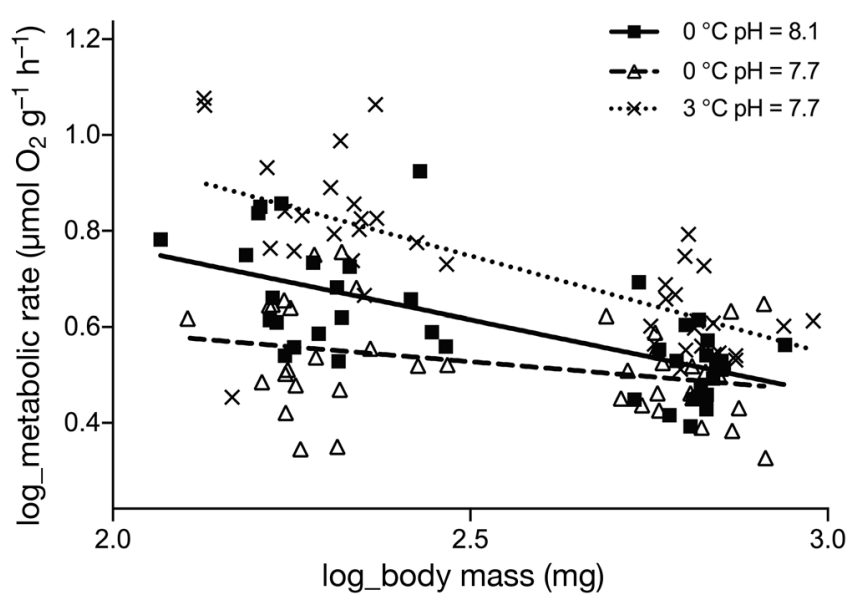

Fig. 7. Mass-specific metabolic rate per gram wet weight (log transformed, $\mu \mathrm{mol} \mathrm{O} \mathrm{g}^{-1} \mathrm{~h}^{-1}$ ) with body mass (log transformed, mg) in smaller (116-294 mg) and larger (490$953 \mathrm{mg}$ ) adult Antarctic krill at various levels of experimental temperature and $\mathrm{pH}$. Ambient temperature and $\mathrm{pH}$ conditions are $0^{\circ} \mathrm{C} / \mathrm{pH}=8.1$. Slopes between treatment groups were significantly different $(\mathrm{p}<0.0001)$

in the high temperature/low pH treatment (Expts 1 and 2) compared to ingestion rates at ambient temperature/pH, whereas ingestion rates increased under low pH in Saba et al. (2012). In the former study, ingestion rates were only significantly affected by $\mathrm{pH}$ in gravid females, suggesting that sex, reproductive condition, and/or maturity state affect how krill respond to the combined effects of elevated temperature and $p \mathrm{CO}_{2}$. Furthermore, the differences relative to acclimation times between the 2 studies (no acclimation in Saba et al. 2012 vs. 48 h in our Expt 1) suggest that even a short exposure to treatment conditions is sufficient for krill to acclimate to changes in seawater chemistry and/or temperature, yielding a vastly different response. In the present study, the response of krill acclimated for $48 \mathrm{~h}$ was consistent with metabolic suppression, similar to that observed in the littoral mysid Praunus flexuosus and the Antarctic pteropod Limacina helicina after prolonged exposure (Seibel et al. 2012, Sperfeld et al. 2017).

Differences in $\mathrm{pH}$ effects on feeding rates (both ingestion and clearance rates) between Expts 1 and 2 could be a function of krill size and/or acclimation time. Feeding rates (Expt 1) were affected by $\mathrm{pH}$ only in the smaller krill size range (30-36 mm, 100$300 \mathrm{mg}$ ). Krill in feeding Expt 2 were larger, which is consistent with the lack of $p \mathrm{CO}_{2}$ effects observed in larger krill in the acid-base, growth, and metabolic experiments. Therefore, larger (non-gravid) adults may have the capacity for physiological resilience with increasing environmental $p \mathrm{CO}_{2}$. The present study also demonstrates that krill may continue acclimating to changes in $\mathrm{pH}$ over the course of $21 \mathrm{~d}$, as indicated by a smaller effect of $\mathrm{pH}$ on feeding rates in krill in Expt 2 (21 d acclimation) compared to Expt 1 (48 $\mathrm{h}$ acclimation). A similar effect of elevated $p \mathrm{CO}_{2}$ on ingestion rates also occurred in North Pacific krill E. pacifica over a $21 \mathrm{~d}$ acclimation period (Cooper et al. 2016).

Feeding rates in Expt 2, however, were still significantly lower in the high temperature/low $\mathrm{pH}$ treatment. A confounding factor was the low initial concentration of chl a in the high temperature/low $\mathrm{pH}$ treatment in Expt 2 (mean $=0.39 \mu \mathrm{g}^{-1}$ ), which may have been too low to stimulate krill feeding behavior (Price et al. 1988). Why the initial chl a concentration was low in this treatment is unknown, as all treatments were prepared following the same protocols. Although this confounding factor precludes a meaningful comparison of the effects of combined high temperature/low $\mathrm{pH}$ between these 2 experiments, our results suggest that warming and/or acidification may have indirectly impacted krill feeding behavior in the present study by reducing phytoplankton biomass. Comparison of chl a concentrations between $\mathrm{T}_{0}$ and $\mathrm{T}_{\text {final }}$ in the controls showed steep declines over time in the ambient temperature/low $\mathrm{pH}$ and high temperature/low $\mathrm{pH}$ treatments in both Expts 1 and 2. However, we were unable to determine if this decrease in chl a was due to reduced phytoplankton growth, a change in community composition, microzooplankton grazing, and/or other factors. Phytoplankton exhibit significant heterogeneity in their responses to ocean acidification (reviewed by Hancock et al. 2020), but most studies on Antarctic phytoplankton species or communities show negligible differences in chlorophyll concentrations between ambient and high $p \mathrm{CO}_{2}$ levels near 1000 ppm (e.g. Davidson et al. 2016, Deppeler et al. 2018, Westwood et al. 2018). However, changes in Antarctic phytoplankton community composition have been reported in response to elevated $p \mathrm{CO}_{2}$ (e.g. Hoppe et al. 2013, Davidson et al. 2016). Additionally, interactive effects of warming and ocean acidification favored the Antarctic diatom Pseudo-nitzschia subcurvata over the prymnesiophyte Phaeocystis antarctica (Zhu et al. 2017).

Additionally, microzooplankton grazing activity was possibly enhanced under elevated temperature and/or $p \mathrm{CO}_{2}$. Although few studies have assessed microzooplankton grazing rates under these conditions, a species of tintinnid ciliate and a heterotrophic dinoflagellate increased ingestion rates of the phytoplankton prey item Emiliania huxleyi under elevated 
$p \mathrm{CO}_{2}$ (Olson et al. 2018), and Ross Sea microzooplankton abundance increased by $43 \%$ after a $1 \mathrm{wk}$ incubation at $4^{\circ} \mathrm{C}$ (Rose et al. 2009). An increase in microzooplankton abundance in our low $\mathrm{pH}$ treatments would have provided an alternative food source for krill during our feeding experiments. Clearance and ingestion rates on ciliate-carbon were not significantly different between $\mathrm{pH}$ treatments and were much lower relative to feeding rates on chlorophyll reported by Saba et al. (2012), but the independent or combined effect of temperature was not tested in that study. Additional investigation is required to address potential mechanisms of changing phytoplankton biomass under warming and ocean acidification conditions, either directly through changes in growth rates or community composition or indirectly through variations in microzooplankton grazing.

\subsection{Growth processes and survival}

The effects of temperature (Poleck \& Denys 1982, Buchholz 1991, Atkinson et al. 2006, Tarling et al. 2006, Brown et al. 2010) and ocean acidification (Sperfeld et al. 2014, 2017, Cooper et al. 2017, Ericson et al. 2018, Opstad et al. 2018) on molting and growth of E. superba or similar species have been independently studied, but to our knowledge no studies have addressed their combined effects. Results from the present study suggest that temperature, rather than ocean acidification, was a dominant driver of krill growth processes, although further study is needed to verify this finding. The warmer temperature resulted in a shorter IMP and lower growth rates, with no effect from $\mathrm{pH}$. As a result of the strong link between IMP and temperature, most of the krill that molted twice during the experiment were from the high temperature treatments. Previous studies found a similar decrease in post-larval krill growth rates at higher temperatures: Atkinson et al. (2006) at temperatures $>1^{\circ} \mathrm{C}$ and Brown et al. (2010) at both 1 and $3{ }^{\circ} \mathrm{C}$. The IMP values determined by Brown et al. (2010) were $24 \mathrm{~d}$ at $1{ }^{\circ} \mathrm{C}$ and $19 \mathrm{~d}$ at $3^{\circ} \mathrm{C}$, similar to IMP values in the present study $\left(23 \mathrm{~d}\right.$ at $0^{\circ} \mathrm{C}$ and $17 \mathrm{~d}$ at $\left.3^{\circ} \mathrm{C}\right)$. Also similar to the present study, the IMP of the north Atlantic euphausiid Nyctiphanes couchii did not change under elevated $p \mathrm{CO}_{2}$ (Sperfeld et al. 2014), although juvenile Praunus flexuosus (mysid) showed an increased IMP with increasing $p \mathrm{CO}_{2}$ (Sperfeld et al. 2017). Although $p \mathrm{CO}_{2}$ reduced growth rates in other crustaceans (Wickins 1984, Kurihara et al.
2008, McLean et al. 2018) and the krill species E. pacifica (Cooper et al. 2017), the present study and previous studies found no significant impact of $p \mathrm{CO}_{2}$ on growth in krill (adult Antarctic krill during a $1 \mathrm{yr}$ perturbation experiment in Ericson et al. 2018; North Atlantic krill in Sperfeld et al. 2014, Opstad et al. 2018). For E. superba, IMP and growth are so strongly affected by temperature that assessing the combined effect of temperature and $\mathrm{pH}$ would likely require much longer incubations than were feasible during this field season.

There is a great deal of complexity inherent in determining growth rate and IMP in krill. Both are likely influenced by factors in addition to temperature (e.g. time in captivity, food, container size, life history stage, etc.), but these causal relationships could not be distinguished in the present study due to time limitations and small sample size. Although negative growth suggests suboptimal conditions, adult krill are known to shrink in relation to season, sex, maturity stage, food quantity and quality, time in captivity, and container size (Siegel 1986, Price et al. 1988, Nicol 2000, Ross et al. 2000, Kawaguchi et al. 2006, Meyer 2012, Meyer \& Teschke 2016, Tarling et al. 2016). Kawaguchi et al. (2006) found that growth rates decreased over the course of the austral summer season and were close to zero or negative by April. Thus, there may have been a seasonal effect on growth rates in the present study, which took place from February to early March. In addition, previous work suggests that in captivity, krill growth rates decrease (Kawaguchi et al. 2006) and processes such as feeding, growth, and respiration do not occur at natural rates (Buchholz 1991, Quetin et al. 1994, Tarling et al. 2006). Container size may also impact krill behavior, particularly feeding behavior. Although krill grew larger in $19 \mathrm{l}$ buckets during the $21 \mathrm{~d}$ acclimation period of the 2014 feeding experiment presented here, another feeding study using smaller containers (5 1), similar to the size used in the growth experiment (4 1), found that krill tended to bump into the sides or swim around the circumference of the bottle without feeding (Price et al. 1988). There is also increasing evidence that growth and IMP differ between females and males (Buchholz et al. 1996, Atkinson et al. 2006, Tarling et al. 2006, Brown et al. 2010). Tarling et al. (2006) suggested that the IMP of males was likely to be $50 \%$ longer than that of females of similar size, particularly at temperatures above $2^{\circ} \mathrm{C}$. Thus, the sex ratio in an experiment may influence average growth and IMP, an effect that may be exacerbated when comparing temperatures below and above $2^{\circ} \mathrm{C}$. Future experi- 
mental designs should consider these complex aspects of the life history of E. superba.

There was an indication of decreased survival at high temperature $(58 \%$ at high temperature/low $\mathrm{pH}$ and $67 \%$ at high temperature/ambient $\mathrm{pH}$ ) compared to ambient $(90 \%$ at ambient temperature $/ \mathrm{pH}$ and $98 \%$ at ambient temperature/low $\mathrm{pH}$ ); however, additional studies are needed to verify this finding. Further, the slightly lower growth rate in the high temperature/ambient $\mathrm{pH}$ treatment in the 2015 growth experiment is likely a result of the small sample size $(n=7)$, which was affected by the anomalously high mortality $(\mathrm{n}=6)$ in this treatment group compared to the low mortality in the high temperature $/ \mathrm{pH}=7.5$ and high temperature $/ \mathrm{pH}=7.1$ treatments ( $\mathrm{n}=1$ per treatment). A previous long-term study of E. superba found that $\sim 75 \%$ of mortality occurred in relation to ecdysis (Poleck \& Denys 1982). Therefore, mortality in the 2015 growth experiment may not have been directly caused by treatment conditions. Instead, mortality was likely related to post-molt condition issues not apparent in the appearance or behavior of the krill, and the occurrence of these individuals in the high temperature/ ambient $\mathrm{pH}$ treatment could have been a mere coincidence. The likelihood that elevated $p \mathrm{CO}_{2}$ enhanced survival seems low, as mortality was low in all other treatments in the present study, and increased survival at elevated $p \mathrm{CO}_{2}$ has not been observed in other published ocean acidification studies focused on multiple krill species (Sperfeld et al. 2014, Cooper et al. 2017, Ericson et al. 2018, Opstad et al. 2018). The present study provides an enticing first look at the combined effects of temperature and $\mathrm{pH}$ on growth, IMP, and survival, but a full understanding will require further studies with larger sample sizes.

\subsection{Physiological processes}

High $p \mathrm{CO}_{2}$ resulted in slight increases in both tissue $\mathrm{TCO}_{2}$ and tissue $\mathrm{pH}_{i}$ however, these disturbances were moderate and transient with a return to baseline by $24 \mathrm{~h}$. There was also a tendency for tissue $\mathrm{TCO}_{2}$, tissue $\mathrm{pH}$, and blood $\mathrm{pH}$ to increase with time over the first $12 \mathrm{~h}$ regardless of treatment. This trend appears related to a substantial lactic acidosis that may have been caused by handling stress and resolved within 24 to $48 \mathrm{~h}$ of exposure.

Metabolic rates increased with temperature. A precise temperature coefficient could not be determined due to the different scaling coefficients between the
2 temperatures. Under low $\mathrm{pH}$ conditions, the high temperature $\left(3^{\circ} \mathrm{C}\right)$ treatment scaled with body mass with a greater slope relative to the ambient temperature $\left(0^{\circ} \mathrm{C}\right)$ treatment under low $\mathrm{pH}$ conditions (Fig. 7). At the smaller end of the size range, metabolic rates were $48 \%$ lower at ambient temperature/low pH compared to those rates at high temperature/low $\mathrm{pH}$. This difference declined to $24 \%$ at the larger end of the size range. These values are equivalent to a $Q_{10}$ of 8.33 and 2.75 at the smaller and larger end of the size range, respectively. By comparing our results to literature findings, we infer that $\mathrm{pH}$ likely had no effect on metabolic rates of larger krill at $3^{\circ} \mathrm{C}$ because the metabolic scaling coefficient at $3^{\circ} \mathrm{C}$ and low $\mathrm{pH}$ and/or the temperature effect at large size and low $\mathrm{pH}$ reported in the present study were within the range previously reported for euphausiids (Ikeda 2013) and for E. superba specifically (Tarling 2020) at ambient $\mathrm{pH}$. Additionally, the rates measured at $3^{\circ} \mathrm{C}$ and low $\mathrm{pH}$ in the present study are within the range previously reported at similar temperatures $\left(2-5^{\circ} \mathrm{C}\right)$ at ambient $\mathrm{pH}$ (rates compiled by Meyer \& Teschke 2016, Tarling 2020).

At the colder temperature $\left(0^{\circ} \mathrm{C}\right)$, high $\mathrm{pCO}_{2}$ dramatically reduced the scaling coefficient, suggesting a pronounced metabolic suppression amongst smaller animals. This suppression likely contributed to the large temperature effect observed in small krill held at low $\mathrm{pH}$. Metabolic suppression is typically an evolved response to resource limitation, sometimes triggered by $\mathrm{pH}$ or $\mathrm{pCO}_{2}$ (Seibel \& Fabry 2003, Melzner et al. 2020). For krill, resources may be limited during over-winter periods spent in deeper waters where $p \mathrm{O}_{2}$ is reduced and $p \mathrm{CO}_{2}$ is elevated (McNeil et al. 2010, Meyer 2012). Although we did not find any prolonged intra- or extracellular acid-base disturbances that could explain the metabolic suppression, acid-base parameters were only measured in larger krill, for which metabolism was unaffected. If a sizable extracellular (blood) acid-base disturbance in smaller krill occurred, blood-oxygen binding affinity would have also been impacted due to the large Bohr coefficient (reported by Bridges et al. 1983), which could cause oxygen limitation and lead to the reduced metabolic rates evident in the smaller size range. Given the reduction in metabolic rate in smaller krill and the absence of any substantial acid-base disturbance in larger krill, costs of ion transport and acid-base regulation may not be a significant factor for krill. This species apparently possesses substantial buffering and acid-base regulatory capacity (Ericson et al. 2018). 


\section{CONCLUSIONS}

Future ocean condition scenarios include a combination of warming temperatures, increasing ocean acidification, and possible additional stressors such as decreasing dissolved oxygen levels. Our study examined the combined effects of ocean acidification and warming temperature and found that shorterterm effects were primarily due to decreased environmental $\mathrm{pH}$, and krill were able to acclimate to these conditions in a matter of hours to days. However, krill size was a factor in acclimation potential, with preliminary evidence that smaller adults may be more susceptible to immediate negative impacts with ocean acidification. Longer-term effects were primarily due to elevated temperature, and krill may need to compensate for these impacts through efficient energetic partitioning or higher consumption of prey. Therefore, food intake and availability should be considered when determining how krill will respond to environmental change.

How krill populations will tolerate future climate change in the Antarctic remains an open question. High variability across studies and among individual animals prompts the need for additional research with an improved experimental approach to maximize sample size, prolong exposure to treatment conditions, and incorporate details including food quantity and quality as well as life history stage. Laboratory studies must also account for differences between conditions in captivity and the open ocean, particularly container size and differences in the prey field. Future studies would benefit from determining threshold food concentrations. Additional multi-stressor experiments with prolonged exposure periods would further elucidate the underlying physiological mechanisms of ocean acidification- and temperature- induced responses, potential costs of increased energetic demand, potential acclimation of krill to ocean acidification and warming, and associated feedbacks on the ecosystem and biogeochemical cycles.

Data availability. Data presented in this paper are available at: https://www.bco-dmo.org/project/721363.

Acknowledgements. We thank Rutgers University undergraduate alumni Ryan Fantasia and Monisha Sugla for their assistance in the field. We thank Deborah Steinberg, Joseph Cope, Kate Ruck, and the crew of the ARSV 'Laurence M. Gould' for collection of Antarctic krill for these experiments during our field seasons at Palmer Station. We thank the Palmer Station staff for their support during each field season. We thank Nicole Waite and Lori Garzio for their assistance on figure preparation and statistical analyses on some components of the data. This project was funded by the
National Science Foundation's Office of Polar Programs (OPP-1246293, OPP-1246349, OPP-1641198).

\section{LITERATURE CITED}

Atkinson A, Siegel V, Pakhomov E, Rothery P (2004) Longterm decline in krill stock and increase in salps within the Southern Ocean. Nature 432:100-103

Atkinson A, Shreeve RS, Hirst AG, Rothery P and others (2006) Natural growth rates in Antarctic krill (Euphausia superba): II. Predictive models based on food, temperature, body length, sex, and maturity stage. Limnol Oceanogr 51:973-987

Atkinson A, Hill SL, Pakhomov EA, Siegel V and others (2019) Krill (Euphausia superba) distribution contracts southward during rapid regional warming. Nat Clim Change 9:142-147

Baumann H (2019) Experimental assessments of marine species sensitivities to ocean acidification and co-stressors: How far have we come? Can J Zool 97:399-408

*Bernard KS, Steinberg DK, Schofield OME (2012) Summertime grazing impact of the dominant macrozooplankton off the Western Antarctic Peninsula. Deep Sea Res I 62: 111-122

Birk MA, McLean EL, Seibel BA (2018) Ocean acidification does not limit squid metabolism via blood oxygen supply. J Exp Biol 221:jeb187443

Bopp L, Resplandy L, Orr JC, Doney SC and others (2013) Multiple stressors of ocean ecosystems in the 21st century: projections with CMIP5 models. Biogeosciences 10: 6225-6245

Breitburg DL, Salisbury J, Bernhard JM, Cai WJ and others (2015) And on top of all that...coping with ocean acidification in the midst of many stressors. Oceanography 28: 48-61

Bridges C, Savel A, Stöcker W, Markl J, Linzen B (1983) Structure and function of krill (Euphausia superba) haemocyanin - adaptation to life at low temperature. Life Chem Rep 1:353-356

* Brown M, Kawaguchi S, Candy S, Virtue P (2010) Temperature effects on the growth and maturation of Antarctic krill (Euphausia superba). Deep Sea Res II 57:672-682

Buchholz F (1991) Moult cycle and growth of Antarctic krill Euphausia superba in the laboratory. Mar Ecol Prog Ser 69:217-229

Buchholz F, Watkins JL, Priddle J, Morris DJ, Ricketts C (1996) Moult in relation to some aspects of reproduction and growth in swarms of Antarctic krill, Euphausia superba. Mar Biol 127:201-208

Clements JC, Darrow ES (2018) Eating in an acidifying ocean: a quantitative review of elevated $\mathrm{CO}_{2}$ effects on the feeding rates of calcifying marine invertebrates. Hydrobiologia 820:1-21

* Cooper HL, Potts DC, Paytan A (2016) Metabolic responses of the North Pacific krill, Euphausia pacifica, to shortand long-term $p \mathrm{CO}_{2}$ exposure. Mar Biol 163:207

Cooper HL, Potts DC, Paytan A (2017) Effects of elevated $p \mathrm{CO}_{2}$ on the survival, growth, and moulting of the Pacific krill species, Euphausia pacifica. ICES J Mar Sci 74: 1005-1012

Wavidson AT, McKinlay J, Westwood K, Thomson PG and others (2016) Enhanced $\mathrm{CO}_{2}$ concentrations change the structure of Antarctic marine microbial communities. Mar Ecol Prog Ser 552:93-113 
Deppeler S, Petrou K, Schulz KG, Westwood K, Pearce I, McKinlay J, Davidson A (2018) Ocean acidification of a coastal Antarctic marine microbial community reveals a critical threshold for $\mathrm{CO}_{2}$ tolerance in phytoplankton productivity. Biogeosciences 15:209-231

Deutsch C, Penn JL, Seibel B (2020) Metabolic trait diversity shapes marine biogeography. Nature 585:557-562

Dickson AG, Sabine CL, Christian JR (2007) Guide to best practices for ocean $\mathrm{CO}_{2}$ measurements. PICES Spec Publ 3:1-191

Ducklow HW, Kirchman DL, Quinby HL, Carlson CA, Dam HG (1993) Stocks and dynamics of bacterioplankton carbon during the spring bloom in the eastern North Atlantic Ocean. Deep Sea Res II 40:245-263

Ericson JA, Hellessey N, Kawaguchi S, Nicol S, Nichols PD, Hoem N, Virtue P (2018) Adult Antarctic krill proves resilient in a simulated high $\mathrm{CO}_{2}$ ocean. Commun Biol 1: 190

Ericson JA, Hellessey N, Kawaguchi S, Nichols PD, Nicol S, Hoem N, Virtue P (2019) Near-future ocean acidification does not alter the lipid content and fatty acid composition of adult Antarctic krill. Sci Rep 9:12375

Everson E (2000) Krill. Biology, ecology and fisheries. Blackwell Science, Cambridge

Flores H, Atkinson A, Kawaguchi A, Krafft BA and others (2012) Impact of climate change on Antarctic krill. Mar Ecol Prog Ser 458:1-19

Hancock AM, King CK, Stark JS, McMinn A, Davidson AT (2020) Effects of ocean acidification on Antarctic marine organisms: a meta-analysis. Ecol Evol 10:4495-4514

Hand SC (1998) Quiescence in Artemia franciscana embryos: reversible arrest of metabolism and gene expression at low oxygen levels. J Exp Biol 201:1233-1242

Heuer RM, Grosell M (2016) Elevated $\mathrm{CO}_{2}$ increases energetic cost and ion movement in the marine fish intestine. Sci Rep 6:34480

*Hoppe CJM, Hassler CS, Payne CD, Tortell PD, Rost B, Trimborn S (2013) Iron limitation modulates ocean acidification effects on Southern Ocean phytoplankton communities. PLOS ONE 8:e79890

$\mathrm{Hu}$ MY, Tseng YC, Stumpp M, Gutowska MA, Kiko R, Lucassen M, Melzner F (2011) Elevated seawater $\mathrm{pCO}_{2}$ differentially affects branchial acid-base transporters over the course of development in the cephalopod Sepa officinalis. Am J Physiol Regul Integr Comp Physiol 300: R1100-R1114

Ikeda T (2013) Respiration and ammonia excretion of euphausiid crustaceans: synthesis toward a global-bathymetric model. Mar Biol 160:251-262

IPCC (2013) Climate change 2013: the physical science basis. Contribution of Working Group I to the Fifth Assessment Report of the Intergovernmental Panel on Climate Change. Cambridge University Press, Cambridge. https: //doi.org/10.1017/CBO9781107415324

* Jokiel PL, Bahr KD, Rodgers KS (2014) Low-cost, high-flow mesocosm system for simulating ocean acidification with $\mathrm{CO}_{2}$ gas. Limnol Oceanogr Methods 12:313-322

Kawaguchi S, Candy SG, King R, Naganobu M, Nicol S (2006) Modelling growth of Antarctic krill. I. Growth trends with sex, length, season, and region. Mar Ecol Prog Ser 306:1-15

Kawaguchi S, Kurihara H, King R, Hale L and others (2011) Will krill fare well under Southern Ocean acidification? Biol Lett 7:288-291

Kawaguchi S, Ishida A, King R, Raymond B and others (2013)
Risk maps for Antarctic krill under projected Southern Ocean acidification. Nat Clim Change 3:843-847

Klein ES, Hill SL, Hinke JT, Phillips T, Watters GM (2018) Impacts of rising sea temperature on krill increase risks for predators in the Scotia Sea. PLOS ONE 13:e0191011

Kroeker KJ, Kordas RL, Crim R, Hendriks IE and others (2013) Impacts of ocean acidification on marine organisms: quantifying sensitivities and interaction with warming. Glob Change Biol 19:1884-1896

Kroeker KJ, Kordas RL, Harley CDG (2017) Embracing interactions in ocean acidification research: confronting multiple stressor scenarios and context dependence. Biol Lett 13:20160802

Kurihara H, Matsui M, Furukawa H, Hayashi M, Ishimatsu A (2008) Long-term effects of predicted future seawater $\mathrm{CO}_{2}$ conditions on the survival and growth of the marine shrimp Palaemon pacificus. J Exp Mar Biol Ecol 367: $41-46$

Kangenbuch M, Pörtner HO (2004) High sensitivity to chronically elevated $\mathrm{CO}_{2}$ levels in a eurybathic marine sipunculid. Aquat Toxicol 70:55-61

* Maas AE, Wishner K, Seibel BA (2012) The metabolic response of pteropods to ocean acidification reflects natural $\mathrm{CO}_{2}$-exposure in oxygen minimum zones. Biogeosciences 9:747-757

*Marin V, Huntley ME, Frost B (1986) Measuring feeding rates of pelagic herbivores: analysis of experimental design and methods. Mar Biol 93:49-58

* McLean EL, Katenka NV, Seibel BA (2018) Decreased growth and increased shell disease in early benthic phase Homarus americanus in response to elevated $\mathrm{CO}_{2}$. Mar Ecol Prog Ser 596:113-126

McNeil BI, Matear RJ (2008) Southern Ocean acidification: a tipping point at 450-ppm atmospheric $\mathrm{CO}_{2}$. Proc Natl Acad Sci USA 105:18860-18864

McNeil BI, Tagliabue A, Sweeney C (2010) A multi-decadal delay in the onset of corrosive 'acidified' seawaters in the Ross Sea of Antarctica due to strong air-sea $\mathrm{CO}_{2}$ disequilibrium. Geophys Res Lett 37:L19607

McWhinnie MA, Marciniak P (1964) Temperature responses and tissue respiration in Antarctic Crustacea with particular reference to the krill Euphausia superba. In: Lee MO (ed) Biology of the Antarctic seas. American Geophysical Union, Washington, DC, p 63-72

* Melzner F, Mark FC, Seibel BA, Tomanek L (2020) Ocean acidification and coastal marine invertebrates: tracking $\mathrm{CO}_{2}$ effects from seawater to the cell. Annu Rev Mar Sci $12: 499-523$

Meyer B (2012) The overwintering of Antarctic krill, Euphausia superba, from an ecophysiological perspective. Polar Biol 35:15-37

Meyer B, Teschke M (2016) Physiology of Euphausia superba. In: Siegel V (ed) Biology and ecology of Antarctic krill. Springer International Publishing, Cham, p 145-174

*Negrete-García G, Lovenduski NS, Hauri C, Krumhardt KM, Lauvset SK (2019) Sudden emergence of a shallow aragonite saturation horizon in the Southern Ocean. Nat Clim Change 9:313-317

Nicol S (2000) Understanding krill growth and aging: the contribution of experimental studies. Can J Fish Aquat Sci 57:168-177

Nicol S, Stolp M, Cochran T, Geijsel P, Marshall J (1992) Growth and shrinkage of Antarctic krill Euphausia superba from the Indian sector of the Southern Ocean during summer. Mar Ecol Prog Ser 89:175-181 
Olson MB, Solem K, Love B (2018) Microzooplankton grazing responds to simulated ocean acidification indirectly through changes in prey cellular characteristics. Mar Ecol Prog Ser 604:83-97

Opstad I, Mangor-Jensen A, Sperfeld E, Johansen IS, Fransson A, Chierici M, Dalpadado P (2018) Effects of high $p \mathrm{CO}_{2}$ in the northern krill Thysanoessa inermis in relation to carbonate chemistry of its collection area, Rijpfjorden. Mar Biol 165:116

Orr JC, Fabry VJ, Aumont O, Bopp L and others (2005) Anthropogenic ocean acidification over the twenty-first century and its impact on calcifying organisms. Nature 437:681-686

Parsons TR, Maita Y, Lalli CM (1984) A manual of chemical and biological methods for seawater analysis. Pergamon Press, New York, NY

* Perissinotto R, Pakhomov EA, McQuaid CD, Froneman PW (1997) In situ grazing rates and daily ration of Antarctic krill Euphausia superba feeding on phytoplankton at the Antarctic Polar Front and the Marginal Ice Zone. Mar Ecol Prog Ser 160:77-91

Pinchuk AI, Hopcroft RR (2007) Seasonal variations in the growth rates of euphausiids (Thysanoessa inermis, $T$. spinifera, and Euphausia pacifica) from the northern Gulf of Alaska. Mar Biol 151:257-269

Poleck TP, Denys CJ (1982) Effect of temperature on the molting, growth and maturation of the Antarctic krill Euphausia superba (Crustacea: Euphausiacea) under laboratory conditions. Mar Biol 70:255-265

Pörtner HO (1990) An analysis of the effects of $\mathrm{pH}$ on oxygen binding by squid (Illex illecebrosus, Loligo pealei) haemocyanin. J Exp Biol 150:407-424

Pörtner HO, Boutilier RG, Tang Y, Toews DP (1990) Determination of intracellular $\mathrm{pH}$ and $p \mathrm{CO}_{2}$ after metabolic inhibition by fluoride and nitrilotriacetic acid. Respir Physiol 81:255-273

Pörtner HO, Langenbuch M, Reipschläger A (2004) Biological impact of elevated ocean $\mathrm{CO}_{2}$ concentrations: lessons from animal physiology and earth history. J Oceanogr 60:705-718

Price HJ, Boyd KR, Boyd CM (1988) Omnivorous feeding behavior of the Antarctic krill Euphausia superba. Mar Biol 97:67-77

Quetin LB, Ross RM (1985) Feeding by Antarctic krill, Euphausia superba: Does size matter? In: Siegfried WR, Condy PR, Laws RM (eds) Antarctic nutrient cycles and food webs. Springer-Verlag, Berlin, p 372-377

Quetin LB, Ross RM (1991) Behavioral and physiological characteristics of the Antarctic krill, Euphausia superba. Am Zool 31:49-63

Quetin LB, Ross RM, Clarke A (1994) Krill energetics: seasonal and environmental aspects of the physiology of Euphausia superba. In: El-Sayed SZ (ed) Southern Ocean ecology: the BIOMASS perspective. Cambridge University Press, Cambridge, p 165-184

Rosa R, Seibel BA (2008) Synergistic effect of climaterelated variables suggests future physiological impairment in a top oceanic predator. Proc Natl Acad Sci USA 105:20776-20780

Rose JM, Feng Y, DiTullio GR, Dunbar RB and others (2009) Synergistic effects of iron and temperature on Antarctic phytoplankton and microzooplankton assemblages. Biogeosciences 6:3131-3147

Ross RM, Quetin LB, Baker KS, Vernet M, Smith RC (2000) Growth limitation in young Euphausia superba under field conditions. Limnol Oceanogr 45:31-43

* Saba GK, Schofield O, Torres JJ, Ombres EH, Steinberg DK (2012) Increased feeding and nutrient excretion of adult Antarctic krill, Euphausia superba, exposed to enhanced carbon dioxide $\left(\mathrm{CO}_{2}\right)$. PLOS ONE 7:e52224

Seibel BA, Fabry VJ (2003) Marine biotic response to elevated carbon dioxide. Adv Appl Biodivers Sci 4:59-67

* Seibel BA, Maas AE, Dierssen HM (2012) Energetic plasticity underlies a variable response to ocean acidification in the pteropod, Limacina helicina antarctica. PLOS ONE 7:e30464

Shaw CT, Peterson WT, Feinberg LR (2010) Growth of Euphausia pacifica in the upwelling zone off the Oregon coast. Deep Sea Res II 57:584-593

Siegel V (1986) Investigations on the biology of Antarctic krill, Euphausia superba, in the Bransfield Strait and adjacent areas. Mitt Inst Seefisch Hambg 38:1-244 (in German)

Sperfeld E, Mangor-Jensen A, Dalpadado P (2014) Effect of increasing seawater $p \mathrm{CO}_{2}$ on the northern Atlantic krill species Nyctiphanes couchii. Mar Biol 161:2359-2370

Sperfeld E, Mangor-Jensen A, Dalpadado P (2017) Effects of increasing $p \mathrm{CO}_{2}$ on life history traits and feeding of the littoral mysid Praunus flexuosus. Mar Biol 164:173

Tarling GA (2020) Routine metabolism of Antarctic krill (Euphausia superba) in South Georgia waters: absence of metabolic compensation at its range edge. Mar Biol 167:108

* Tarling GA, Shreeve RS, Hirst AG, Atkinson A, Pond DW, Murphy EJ, Watkins JL (2006) Natural growth rates in Antarctic krill (Euphausia superba): I. Improving methodology and predicting intermolt period. Limnol Oceanogr 51:959-972

Tarling GA, Hill S, Peat H, Fielding S, Reiss C, Atkinson A (2016) Growth and shrinkage in Antarctic krill Euphausia superba is sex-dependent. Mar Ecol Prog Ser 547: $61-78$

*Torres JJ, Aarset AV, Donnelly J, Hopkins TL, Lancraft TM, Ainley DG (1994) Metabolism of Antarctic micronektonic Crustacea as a function of depth of occurrence and season. Mar Ecol Prog Ser 113:207-219

*Westwood K, Thomson P, van den Enden R, Maher L, Wright S, Davidson A (2018) Ocean acidification impacts primary and bacterial production in Antarctic coastal waters during austral summer. J Exp Mar Biol Ecol 498: $46-60$

Whiteley NM (2011) Physiological and ecological responses of crustaceans to ocean acidification. Mar Ecol Prog Ser 430:257-271

*Wickins JF (1984) The effect of hypercapnic seawater on growth and mineralization in penaeid prawns. Aquaculture 41:37-48

*Wiedenmann J, Cresswell K, Mangel M (2008) Temperature-dependent growth of Antarctic krill: predictions for a changing climate from a cohort model. Mar Ecol Prog Ser 358:191-202

Khang H, Byrne R (1996) Spectrophotometric pH measurements of surface seawater at in-situ conditions: absorbance and protonation behavior of thymol blue. Mar Chem 52:17-25

* Zhu Z, Qu P, Gale J, Fu F, Hutchins DA (2017) Individual and interactive effects of warming and $\mathrm{CO}_{2}$ on Pseudonitzschia subcurvata and Phaeocystis antarctica, two dominant phytoplankton from the Ross Sea, Antarctica. Biogeosciences 14:5281-5295

Submitted: December 13, 2020

Accepted: April 1, 2021

Proofs received from author(s): April 26, 2021
Fort Pierce, Florida, USA

Reviewed by: G. Andrew Tarling and 2 anonymous referees 